\title{
Transposon-mediated BAC transgenesis in zebrafish
}

\author{
Maximiliano L Suster ${ }^{1,2}$, Gembu Abe $^{1}$, Anders Schouw ${ }^{2} \&$ Koichi Kawakami1 ${ }^{1,3}$
}

\begin{abstract}
${ }^{1}$ Division of Molecular and Developmental Biology, National Institute of Genetics, Mishima, Shizuoka, Japan. ${ }^{2}$ Sars International Center for Marine Molecular Biology, University of Bergen, Bergen, Norway. ${ }^{3}$ Department of Genetics, Graduate University for Advanced Studies (SOKENDAI), Mishima, Shizuoka, Japan. Correspondence should be addressed to M.L.S. (maximiliano.suster@sars.uib.no) or K.K. (kokawaka@lab.nig.ac.jp).

Published online 1 December 2011; doi:10.1038/nprot.2011.416

Bacterial artificial chromosomes (BACs) are widely used in studies of vertebrate gene regulation and function because they often closely recapitulate the expression patterns of endogenous genes. Here we report a step-by-step protocol for efficient BAC transgenesis in zebrafish using the medaka Tol2 transposon. Using recombineering in Escherichia coli, we introduce the iTol2 cassette in the BAC plasmid backbone, which contains the inverted minimal cis-sequences required for Tol2 transposition, and a reporter gene to replace a target locus in the BAC. Microinjection of the Tol2-BAC and a codon-optimized transposase mRNA into fertilized eggs results in clean integrations in the genome and transmission to the germline at a rate of $\sim 15 \%$. A single person can prepare a dozen constructs within 3 weeks, and obtain transgenic fish within approximately 3-4 months. Our protocol drastically reduces the labor involved in BAC transgenesis and will greatly facilitate biological and biomedical studies in model vertebrates.
\end{abstract}

\section{INTRODUCTION}

BAC transgenesis has been used extensively in a broad range of applications in mice, from studies of gene regulation to creating animal models of human disease $\mathrm{e}^{1-3}$. Because BACs can hold genomic fragments as large as $300 \mathrm{~kb}$, they often include the complete structure of a gene, including long-range cis-regulatory elements required for correct cell type-specific and temporal expression. Compared with small plasmid-based transgenes, BACs are generally more resistant to positional effects, presumably because of their larger size. BAC transgenic mice have uniquely advanced the analysis of distant cisregulatory elements, rescue of mutant phenotypes and study of human disease-related genes ${ }^{1,2}$. BAC reporter transgenes have been created systematically by recombineering fluorescent reporters in bacteria to visualize specific tissues or cells in living mice ${ }^{4,5}$.

Given the tractability of zebrafish (Danio rerio) for vertebrate genetics, improving the frequency and reliability of BAC transgenesis in this model organism could have a number of important advantages. BAC transgenic zebrafish have been reported for more than 10 years $^{6-8}$; however, systematic generation of BAC reporter lines has not been straightforward. BAC transgenic lines expressing live reporters such as GFP can enhance the usefulness of zebrafish in developmental and evolutionary studies, in modeling human disease $^{9}$, targeted manipulation of neural circuits ${ }^{8}$ and drug screening $^{9}$. As fertilization is external, live embryos are accessible to visualization and manipulation of specific cell types. Furthermore, genetic manipulations by targeted expression of apoptotic genes, neurotoxins and light-activated ion channels have become feasible through the Gal4/UAS ${ }^{10,11}$, LexA/Op ${ }^{12}$, Cre/lox ${ }^{13}$ or TetON ${ }^{14}$ conditional expression systems in zebrafish.

Traditionally, BAC transgenesis has been carried out by microinjection of naked DNA (purified DNA without associated proteins) in the fertilized zebrafish egg ${ }^{6}$ or mouse oocyte ${ }^{1}$. BAC integration in the genome occurs randomly via nonhomologous DNA end joining $^{1}$. A number of reports suggest that BAC DNA microinjection into the cytoplasm of fertilized zebrafish eggs results in approximately $1-3 \%$ (or less) germline transmission ${ }^{6-8}$. Although there are no detailed reports of copy number and fidelity of BAC integration in transgenic zebrafish, extensive studies of BAC transgenesis in mice have shown that approximately half of BAC integrations result in either a single-copy BAC insertion or insertion of multicopy
BAC concatemers at a single genomic locus; the remaining carry between 5 and 48 copies of the BAC in various orientations ${ }^{15}$. Concatemeric transgenes are generally associated with silencing, instability and genetic lesions both inside and around the transgenes ${ }^{16,17}$, potentially limiting important experimental applications. The conditional deletion of a particular DNA sequence within a $\mathrm{BAC}$ using Cre-loxP-mediated recombination ${ }^{2}$ is one such application. In particular, when tandem loxP sites are placed within a BAC flanking a gene or cassette and the BAC transgene is a concatemer, unwanted deletions may occur upon Cre-mediated recombination. Therefore, more reliable methods for BAC transgenesis in zebrafish have been desired.

In the past two decades, a number of transgenesis methods have been developed for zebrafish, yet most are not applicable to BAC transgenesis because of restrictions in DNA cargo capacity (Table 1). Microinjection of naked DNA, in which a linearized construct is introduced into the cytoplasm of one-cell-stage embryos ${ }^{18-21}$, is the simplest and easiest method, but suffers from low integration rates and is unreliable as discussed above. Inclusion of an 18-bp I-SceI meganuclease recognition site in the plasmid DNA and co-injection with I-SceI protein was found to substantially enhance integration rates for small $(\sim 5 \mathrm{~kb})$ constructs $^{22}$; whether this is useful for enhancing integration of BAC constructs in zebrafish is not known. Retroviral vectors have also been successfully used for transgenesis in zebrafish, particularly for genome-wide insertional mutagenesis $^{23-26}$; however, retroviral vectors have a very limited cargo capacity $(<8 \mathrm{~kb})^{27}$ and their application in the laboratory is labor intensive. More recently, attention has turned to transposable elements, including mariner ${ }^{28}$, Tol2 (ref. 29) and Sleeping beauty ${ }^{30}$. Among them, Tol2 appears to have the highest rate of genomic integration in the germ lineage (Table $\mathbf{1}$ ) and is now widely used for transgenesis and forward genetics, including insertional mutagenesis $\mathrm{s}^{31,32}$. Furthermore, we recently demonstrated that Tol2 has a surprisingly large cargo capacity (more than $50 \mathrm{~kb}$ ) and can carry efficiently BAC inserts into the zebrafish and mouse genomes ${ }^{33}$.

The medaka Tol2 element is a DNA-type transposon that is active in a wide variety of vertebrates ${ }^{31-35}$. When cis-sequences from the left and right ends of Tol2 are placed on either side of a DNA insert, the insert can be reliably integrated into the genome via 
TABLE 1 | Comparison of transgenesis methods in zebrafish.

\begin{tabular}{|c|c|c|c|}
\hline Naked DNA ${ }^{18-21}$ & Simple and easy & $\begin{array}{l}\text { Low integration rates: } 5-10 \% \text { for small } \\
\text { constructs }(<10 \mathrm{~kb}) \text { and } 2 \% \text { for BACs } \\
\text { Concatameric integrations }\end{array}$ & $\begin{array}{l}\text { Transgenesis } \\
\text { BAC transgenesis }\end{array}$ \\
\hline Meganuclease $^{22}$ & $\begin{array}{l}\text { Moderate integration rates ( } \sim 30 \% \text { with } \\
\text { prescreen) }\end{array}$ & $\begin{array}{l}\text { Requires construction } \\
\text { Requires I-SceI meganuclease }\end{array}$ & Transgenesis \\
\hline Tol2 (refs. 29,31-36) & $\begin{array}{l}\text { High integration rates: } 50-70 \% \text { for small } \\
\text { constructs (up to } 10 \mathrm{~kb} \text { ) and } 5-20 \% \text { for BACs } \\
\text { Single-copy integrations } \\
\text { End-to-end integrations } \\
\text { Creates clean hits on the genome } \\
\text { Large cargo capacity (>160 kb) }\end{array}$ & $\begin{array}{l}\text { Requires construction } \\
\text { Requires transposase mRNA }\end{array}$ & $\begin{array}{l}\text { Transgenesis } \\
\text { BAC transgenesis } \\
\text { Insertional mutagenesis }\end{array}$ \\
\hline Retrovirus ${ }^{23-27}$ & $\begin{array}{l}\text { High integration rates }(70-100 \%) \\
\text { Single-copy integrations } \\
\text { End-to-end integrations } \\
\text { Creates clean hits on the genome }\end{array}$ & $\begin{array}{l}\text { Low cargo capacity }(<8 \mathrm{~kb}) \\
\text { Requires construction } \\
\text { Laborious viral preparation }\end{array}$ & $\begin{array}{l}\text { Transgenesis } \\
\text { Insertional mutagenesis }\end{array}$ \\
\hline
\end{tabular}

a transposase (TP)-dependent cut-and-paste mechanism ${ }^{34,36}$. By inverting these minimal Tol2 ends, $150 \mathrm{bp}$ on the left and $200 \mathrm{bp}$ on the right, and placing them $\sim 1 \mathrm{~kb}$ apart on a large BAC plasmid, we have found that any insert can be efficiently excised by the Tol 2 TP in fertilized zebrafish eggs or mouse oocytes ${ }^{33}$. By using this inverted minimal Tol2 cassette (iTol2 cassette), we have observed a very high success rate in the integration of BAC transgenes into the zebrafish genome ${ }^{33,37}$, regardless of insert size (range 35-230 kb) or source (five BAC libraries tested from two species). Stable germline BAC integrations are observed in $\sim 15 \%$ of the injected founder fish (range 5-20\%). Notably, reporter expression in the BAC transgenic fish matches the expression pattern of the endogenous gene.

Here we report a step-by-step protocol, including new iTol2 cassettes (iTol2-galactokinase (galK), iTol2-ampicillin (amp) and iTol2kanamycin (kan)), reagents and recent examples from our work that illustrate in detail how to generate BAC transgenic zebrafish efficiently using recombineering technology $y^{38}$ and the Tol2 transposon system. Our protocol complements conventional naked DNA injection by providing increased efficiency and higher reliability to deliver single-copy BAC integrations. This protocol should greatly expand the use of BAC transgenesis in zebrafish, aiding clean and intact BAC integrations and more reliable tools for analysis of gene regulation, comparative genomics and targeted gene expression.

\section{Overview of the procedure}

Generation of BAC transgenic zebrafish with the Tol2 system consists of three stages. A flowchart in Figure 1 outlines these

Figure 1 | Flowchart outlining the experimental procedures described in this protocol and anticipated timing for each step. The double arrow between the boxes 'Steps $16-32$ ' and 'Step 33' indicates that the order can be reversed. The circular arrow on the box 'Step 50' indicates that this step may have to be repeated several times before this part of the procedure is completed. stages and the experimental procedures involved. In the first stage (Steps 1-33), a Tol2-compatible BAC plasmid is constructed in E. coli by recombineering. A BAC clone covering the genomic region of interest is retrieved by searching online databases. The clone is grown in a special strain of E. coli in order to introduce by homologous recombination a reporter gene (such as GFP) at the locus of interest and the iTol2 cassette into the plasmid backbone. In the second stage (Steps 34-48), the BAC transgene is microinjected

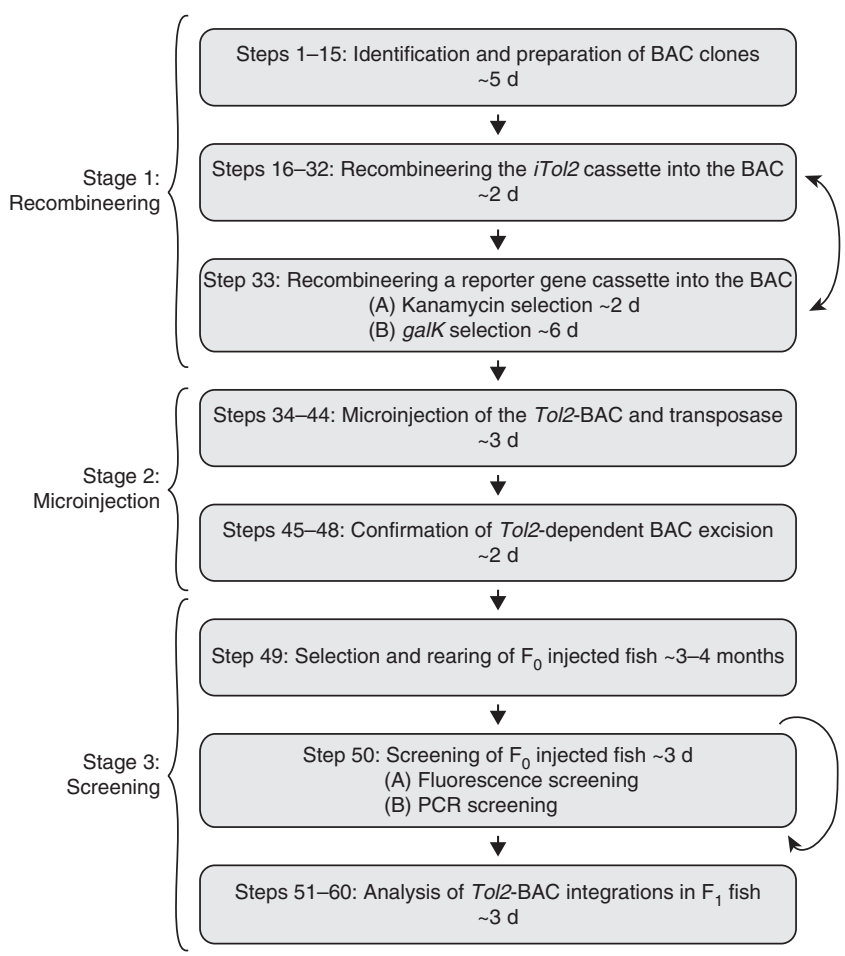


PROTOCOL

TABLE 2 | Zebrafish BAC, PAC and FOS libraries.

\begin{tabular}{llcclc}
\hline Library & Prefix & Ensembl prefix & Insert size $(\mathbf{k b})$ & Vector & Contact \\
CH0RI-211 & CH211 & ZC & 171 & pTARBAC2.1 & bacpacorders@chori.org \\
DanioKey & DKEY & zK & 175 & pIndigoBac-536 & sales@imagenes-bio.de \\
DanioKey Pilot & DKEYP & zKp & 130 & pIndigoBac-536 & sales@imagenes-bio.de \\
CHORI-73 & CH73 & zH & 110 & pTARBAC2.1 & bacpacorders@chori.org \\
RPCI-71 & RP71 & bZ & 85 & pTARBAC2.1 & bacpacorders@chori.org \\
BUSM1 (PAC) & BUSM1 & dZ & 115 & pCYPAC6 & camemiya@benaroyaresearch.org \\
ZFISHF0S & ZFISHF0S & - & 40 & pFOS-1 & archives@sanger.ac.uk \\
CH0RI-1073 (FOS) & CH1073 & zFD & 175 & pCCF0S1 & bacpacorders@chori.org \\
\hline
\end{tabular}

Table modified from http://www.sanger.ac.uk/Projects/D_rerio/faqs.shtml\#dataeight.

into fertilized eggs together with Tol2 TP RNA. In the third stage (Steps 49-60), the injected fish are raised to sexual maturity and screened for transmission of the $B A C$ transgene to the germline by PCR genotyping or fluorescence sorting. Below we describe the background and implementation of the procedure.

Obtaining BAC clones. In general, as the regulatory elements of any gene may be scattered over long distances and located both upstream and downstream of the gene ${ }^{39}$, it is wise to start with the largest possible genomic clones available (at least $100 \mathrm{~kb}$ ). If the gene is too large to be contained in a single BAC, ideally several overlapping BAC clones should be obtained. These clones can be modified and tested in parallel to identify the most appropriate $\mathrm{BAC}$ clone for stable transgenesis. Clones are available from at least eight zebrafish genomic libraries, including CHORI-211, CHORI-73, CHORI-1073, DanioKey and DanioKey Pilot (Table 2). Fosmid clones in the CHORI-1073 library can also be modified by recombineering because the inserts are in the single-copy vector pCCFOS1.

BAC recombineering in E. coli. To modify a BAC clone, DNA sequences in the BAC are exchanged by bacteriophage-mediated homologous recombination systems in E. coli38,40-44. BAC plasmid DNA is introduced by electroporation into the bacterial strain SW102 (derived from DY380), which harbors a defective $\lambda$-Red prophage on the genome that contains the heat-inducible recombinase functions, and a precise deletion of the galK gene $(\Delta g a l K)^{45}$. This strain allows both single-step antibiotic selection and two-step positive/negative galK selection ${ }^{45}$.

Figure 2 | iTol2, kan and galK cassettes for BAC recombineering. (a) Schematic of the medaka Tol2 transposon and design of the iTol2 cassettes. Red triangles represent the left (L200) and right (R150) minimal ends of Tol2 required for transposition. Gray boxes and overlying lines in Tol2 represent the exons of TP mRNA. In piTol2-amp, piTol2-kan and piTol2-galK, the $L$ and $R$ ends of Tol2 have been inverted flanking the ampresistance $(a m p R)$, kan-resistance ( $k a n R)$ and galK genes, respectively. The prokaryotic em7 promoter is included in piTol2-galK. Plasmids carry the Spec-resistance gene (SpecR). (b) Schematic of vectors used for PCR amplification of galK and kanamycin recombineering. Kanamycin selection plasmids encoding GFP, Gal4FF, Gal4VP16 or Cre contain the SV40 pA (gray box), where the kan is flanked by FRT sites.
A linearized PCR product (the cassette) containing a donor sequence and $50 \mathrm{bp}$ homologies to the target sequence on each end is introduced by electroporation into BAC-containing cells ${ }^{41,45}$. The $\lambda$-Red-encoded Gam function prevents degradation of the PCR product, whereas Exo or Red $\alpha$ and Beta or Red $\beta$ mediate recombination. Because Red $\alpha / \operatorname{Red} \beta$ are under the tight control of the temperature-sensitive $\lambda$ repressor (allele $c$ I857) ${ }^{40,41}$, recombination can be induced by shifting the cultures to $42^{\circ} \mathrm{C}$ for $15 \mathrm{~min}$, leading to precise exchange of the target sequence ${ }^{45-49}$.

iTol2 cassette. To facilitate integration of the BAC construct into the genome, a cassette containing the minimal sequences required for Tol2 transposition must be placed inside the BAC plasmid. As $200 \mathrm{bp}$ on the left (L200) and $150 \mathrm{bp}$ on the right end (R150) of the Tol2 transposon are sufficient for efficient transposition in $v_{i v o^{36}}$ (Fig. 2a), we created the iTol2 cassette, which consists of

\section{a}

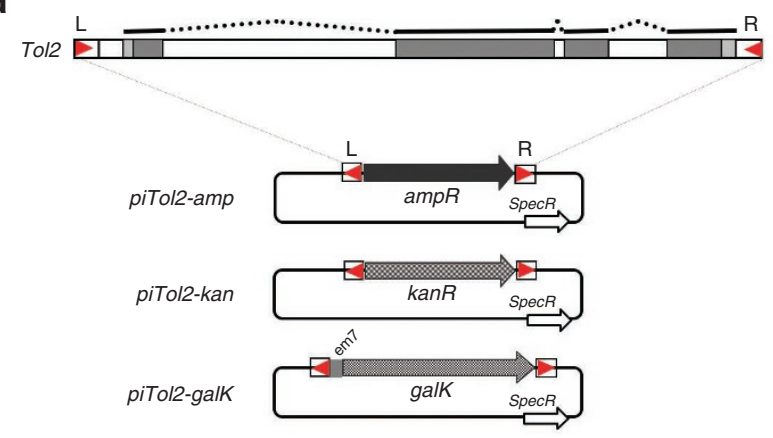

b

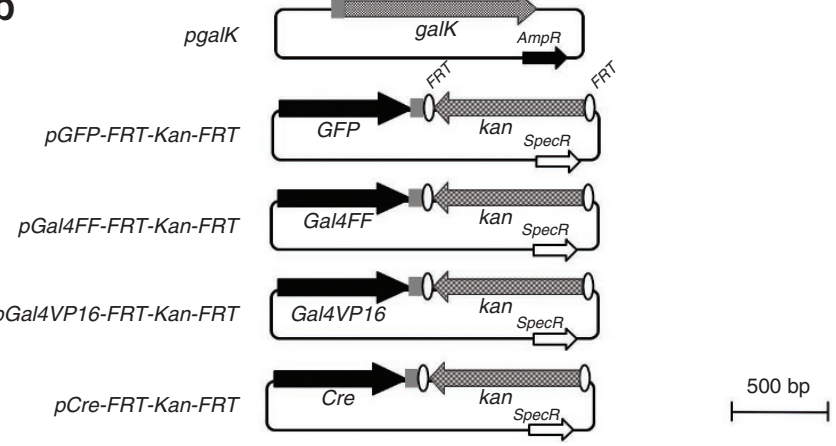


Figure 3 | Recombineering the iTol2 cassette and reporter gene into a BAC clone. (a) iTol2 cassette and kanamycin selection cassette recombineering. The iTol2-amp linear fragment with 50-bp overhangs (small arrows represent primers) matching a sequence flanking a lox $P$ or lox511 site is introduced into the BAC clone, which contains a gene of interest (gene $X$ ). After selection on ampicillin plates, bacteria containing the resulting Tol2-BAC plasmid are electroporated with a PCR product containing GFP and kanamycin flanked by FRT sites, with 50-bp homologies to the first and second exons in the gene. After selection on ampicillin and kanamycin plates, colonies containing the Tol2-BAC reporter are readily obtained. (b) Introducing a reporter gene into the Tol2-BAC by galK recombineering. A PCR-amplified galK product with $50-b p$ homologies to the first and second exons in the gene is electroporated into cells containing the Tol2-BAC reporter. After selection on galactose-only medium, Gal ${ }^{+}$colonies containing the Tol2-BAC:galK are recovered. Next, these colonies are electroporated with a linear PCR product encoding a reporter gene (GFP) to replace the galK cassette. After negative selection on D0G medium, colonies containing the Tol2-BAC:GFP reporter are recovered.

the inverted L200 and R150 sequences flanking the galK-, amp-or kan-resistance genes. To prepare linear double-stranded iTol2 cassette DNA for recombineering, piTol2-galK, piTol2-amp and piTol2-kan (Fig. 2a) are used as templates for PCR.

Reporter gene cassette. Typically, a cassette containing a reporter gene (such as GFP) is placed in a coding exon within the BAC to monitor the expression of a gene of interest. We have constructed several plasmids containing a number of reporter gene cassettes that serve as templates for PCR (Fig. 2b). In these plasmids, the reporter gene (such as GFP) is fused to a strong transcription termination signal (i.e., simian virus $40 \mathrm{pA}$ ) and an antibiotic-resistance gene (kan) flanked by FRT sites. Two of these plasmids encode the Gal4FF ${ }^{10}$ and Gal4-VP16 (refs. 50,51) transcriptional activators, and another the Cre recombinase ${ }^{52}$. Gal4 drives transcription of any target gene located downstream of its target UAS sequence ${ }^{50,51}$, and Cre will delete any sequence located between two adjacent loxP sites $^{52}$. To restrict the activity of Gal4 or Cre in space and time, the cassettes are typically placed under the control of tissue-specific promoters in the $\mathrm{BAC}^{4,5}$.

Introducing the $i T o l 2$ cassette into the BAC clone. The $i T o l 2$ cassette with 50-bp homologies on each end is amplified by PCR and inserted at a fixed location in the BAC plasmid-either a loxP or lox511 site, which is present in the plasmid backbone of most BAC libraries (Fig. 3a). After transformation of the PCR product into BAC-containing cells, and induction of recombineering functions, colonies containing the BAC plasmid with the iTol2-amp cassette (Tol2-BAC plasmid) will grow on ampicillin medium overnight (Fig. 3a).

Introducing the reporter gene into the $\mathrm{BAC}$ clone. The reporter gene is introduced into the Tol2-BAC plasmid using antibiotic selection (Fig. 3a) or two-step galK selection (Fig. 3b). A kan reporter gene cassette (such as GFP-pA-FRT-kan-FRT) is amplified by PCR, together with 50-bp homologies to the first exon and the first intron (or second exon) of the target gene. After transformation of Tol2-BAC-containing cells with the PCR product and induction of recombineering functions, $\mathrm{kan}^{+}$recombinants
(Tol2-BAC:FRT-kan-FRT) are recovered on Luria broth (LB)ampicillin/kanamycin plates the next day (Fig. 3a). Although it is not essential to do so, the kan gene can be excised later on from the Tol2-BAC plasmid by induction of FLPase in E. $\mathrm{coli}^{38,45}$. For $\mathrm{galK}$ selection, a $1.2 \mathrm{~kb}$ galK gene, including the prokaryotic em7 promoter (Fig. 2b) and 50-bp homologies to the BAC target sequence, is amplified by PCR and electroporated into Tol2-BAC-containing cells ${ }^{45}$. Only cells containing galK $\left(\mathrm{gal}^{+}\right)$will grow on galactose minimal medium after $3 \mathrm{~d}$ (Fig. 3b). To replace gal $K$ with a reporter gene, a PCR product containing the gene of interest (such as GFP) and 50-bp homologies is transformed into gal ${ }^{+}$cells. After induction of recombineering functions, cells are plated on minimal medium containing 2-deoxy-D-galactose (DOG), a galactose analog that, after phosphorylation by gal $K$, becomes toxic ${ }^{45}$. Only bacteria containing the Tol2-BAC reporter plasmid without $\mathrm{galK}\left(\mathrm{Gal}^{-}\right)$will survive on DOG-containing medium after $3 \mathrm{~d}$ (Fig. 3b).

Microinjection of the Tol2-BAC plasmid and stable transgenesis. To integrate the BAC construct in the genome, the Tol2-BAC plasmid and synthetic Tol2 TP mRNA are co-injected into the cytoplasm of one-cell-stage embryos ${ }^{53}$ (Fig. 4). Efficient integration of the Tol2$\mathrm{BAC}$ construct in the genome is strongly dependent on the activity of $\mathrm{TP}^{33}$. To increase the translation efficiency of TP mRNA, we recently generated a synthetic $T P$ gene with codon usage optimized for zebrafish $(z T P$, Fig. 4a). Injection of zTP mRNA leads to reliable germline transmission of Tol2-BAC transgenes in $\sim 20 \%$ of injected fish. To confirm that TP is functioning properly and that the BAC plasmid DNA is intact, a simple PCR excision assay is performed on 10-h-old injected embryos (Fig. 4b). TP excises the BAC DNA insert upon binding to the $i T o l 2$ sequences, creating an 8-bp duplication at the target site $e^{34,36}$ (Fig. 4c). If excision occurs, the bacterial selection gene inside the iTol2 cassette is released, and then circularized presumably by self-ligation ${ }^{33,34}$ (Fig. 4b,c). Ideally, nine of ten embryos show an excision product, and if so all injected embryos are raised to sexual maturity. However, if the BAC transgene encodes a fluorescent reporter, it is recommended to raise separately those showing the strongest and most even fluorescence signals from the rest, as stronger signals may be correlated with higher integration rates (M.L.S., unpublished observations). To identify germline carriers 
Figure 4 | Microinjection of the Tol2-BAC plasmid and excision assay. (a) A synthetic zebrafish codon-optimized Tol2 TP CDNA ( $2 T P$ ) was cloned into the pCS2 expression vector. After linearizing this vector with NotI, zTP mRNA is synthesized in vitro from the SP6 promoter. (b) The Tol2-BAC and TP mRNA are co-injected into the cytoplasm of the one-cell embryo. A subset of the injected embryos are grown for $10 \mathrm{~h}$, digested with proteinase $\mathrm{K}$ and processed for a PCR excision assay. The PCR products amplified from the excised iTol2 cassette (see below) are examined on a 1\% (wt/vol) agarose gel. A strong 336-bp band (arrowhead) is detected in embryos co-injected with BAC and TP RNA (+TP mRNA) but not without TP (-TP mRNA). M, 1 kb DNA ladder. (c) Schematic of Tol2-dependent excision and integration of the Tol2-BAC transgene in the genome. TP protein (black circles) binds to the iTol2 ends in the Tol2-BAC plasmid (pTol2-BAC), leading to excision of the amp gene (blue arrow) that is circularized by ligation. This excision product can be amplified by PCR (using the forward ( $f$ ) and reverse ( $r$ ) primers). The Tol2 ends of the excised BAC plasmid align with a random target site (asterisk) in the genomic DNA, followed by stable integration and duplication of the 8-bp target sequence (asterisks). AmpR, amp resistance.

among injected (founder) fish, the progeny are screened by PCR or fluorescent sorting. We recommend screening at least 50 (but preferably 100) embryos from each founder.

\section{Advantages, applications and limitations}

Two major advantages of Tol2-mediated BAC transgenesis over existing methods are increased efficiency of germline transmission and greater reliability of obtaining single-copy integrations in the genome (Table 1). BAC transgenic fish expressing fluorescent proteins in specific cells and tissues have a wide range of unique applications in basic and applied fields of biology and medicine. These include live imaging of cells and subcellular structures in complex tissues and organs such as the nervous system ${ }^{8}$. Other applications include rescue of mutant phenotypes, mechanistic studies of human disease ${ }^{9}$, targeted cell ablation and manipulation of neural circuits ${ }^{54}$, drug screening ${ }^{9}$ and functional analysis of gene regulatory elements ${ }^{6,37}$. Because the $i T o l 2$ sequences can be added in a single recombineering step to many BACs at once, our protocol can uniquely facilitate the systematic generation of $\mathrm{BAC}$ transgenic fish. One limitation of our protocol is that clones maintained in multicopy plasmids such as cosmids (30-50 kb) are not readily modifiable by recombineering ${ }^{38}$. In addition, target regions containing repetitive or incorrect sequences can pose obstacles to recombineering. Although we are not aware of any size limitation on Tol2-mediated BAC transgenesis, this has yet to be determined.

\section{Experimental design}

Choice of BAC clone. Given the number of vertebrates with sequenced genomes, there are in principle a large number of possible sources of BAC clones for transgenesis in zebrafish. Although most mammalian promoters are not likely to work in transgenic zebrafish $^{55}$, BACs from closely related teleost fish, such as the pufferfish Fugu rubripes, are known to work properly in zebrafish ${ }^{37}$ and are useful tools for comparative genomic studies. Such BAC clones may be useful when zebrafish BACs are not available for a particular genomic region or when this region contains excessive repeats. Table 3 lists information regarding BAC libraries from several model fish species with sequenced genomes.

Choice of recombineering system. Two recombineering systems commonly used are the $\lambda$-Red system (the one used in this a
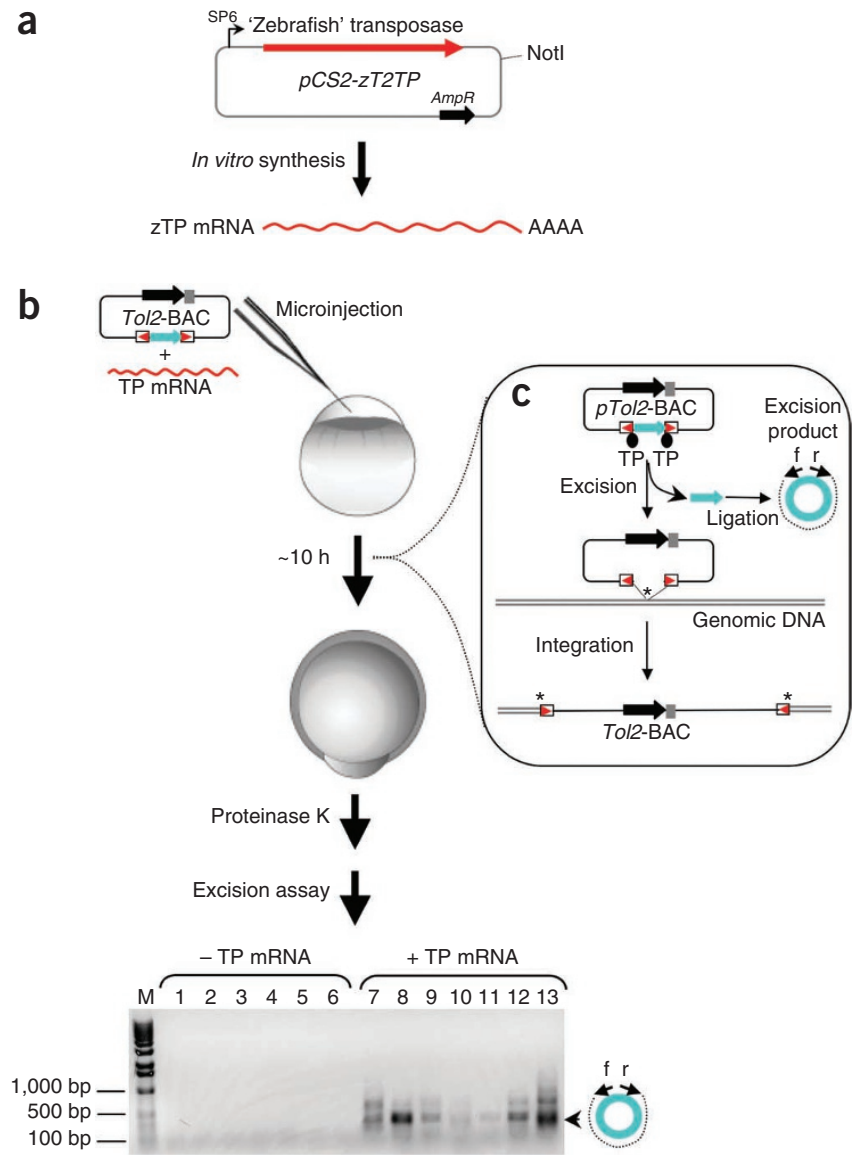

protocol) and the RecET system from the Rac prophage ${ }^{38}$. Both systems permit recombination using double-stranded fragments with short (40-60 bp) homologies ${ }^{40-44}$. To supply the recombination functions, there are two options. One is to use a bacterial strain that harbors the genes encoding these functions (such as SW102). Another option is to supply a plasmid that contains these genes (such as pSIM18 (ref. 56)). The latter could be useful to avoid the preparation of BAC plasmid DNA before recombineering. On the other hand, new bacterial strains containing the recombineering functions, such as SW105 and SW106 (derivates of SW102), offer advantages as well, such as the presence of arabinose-inducible Cre or FLP in the E. coli genome, which permit the excision of cassettes flanked by loxP or FRT sites, respectively ${ }^{45}$.

Cassette design and recombineering procedure. Construction of Tol2-BAC transgenes may require several rounds of recombineering and cassettes. Thus, the size of the cassette, selection marker ( $a m p$, kan and $g a l K$ ), target sequence and procedure should be carefully considered. Although homologous exchange of DNA up to $2 \mathrm{~kb}$ is straightforward, larger cassettes $(>5 \mathrm{~kb}$ ) require cloning longer homology arms around 200-500 bp because of the lower efficiency of homologous recombination ${ }^{38}$. Subcloning is more laborious and large cassettes are more prone to mutagenesis during PCR. If a cassette has a generic function (such as the iTol2 cassette), it should be inserted at a fixed location in the BAC plasmid, thus simplifying the process and saving costs. As long as the target site does not contain repetitive sequences, it should be possible to insert the cassette almost anywhere in the BAC. 
TABLE 3 | BAC libraries from alternative fish species with annotated genomes.

\begin{tabular}{|c|c|c|c|c|c|}
\hline $\begin{array}{l}\text { Pufferfish (Takifugu } \\
\text { rubripes) }\end{array}$ & Fugu & 80 & pBeloBAC11 & http://fugu.nimr.mrc.ac.uk/ & $\begin{array}{l}\text { Source BioScience (lifesciences@ } \\
\text { sourcebioscience.com) }\end{array}$ \\
\hline $\begin{array}{l}\text { Green spotted pufferfish } \\
\text { (Tetraodon nigroviridis) }\end{array}$ & A & 126 & pBACe3.6 & $\begin{array}{l}\text { http://www.genoscope.cns. } \\
\text { fr/externe/tetranew/ }\end{array}$ & $\begin{array}{l}\text { Genoscope (webmaster@genoscope. } \\
\text { cns.fr) }\end{array}$ \\
\hline \multirow[t]{2}{*}{ Medaka (Oryzias latipes) } & $H d-r R$ & 210 & pBAC-lac & http://medaka.utgenome.org/ & $\begin{array}{l}\text { Medaka Bioresource Center (mbrc@ } \\
\text { nibb.ac.jp) }\end{array}$ \\
\hline & $\mathrm{Hd}-\mathrm{rR} / \mathrm{HNI}$ & & pBAC-lac & $\begin{array}{l}\text { http://earth.lab.nig.ac.jp/ } \\
\sim \text { mbase/mb_base.html }\end{array}$ & MMBase (mbase@k.u-tokyo.ac.jp) \\
\hline \multirow[t]{2}{*}{$\begin{array}{l}\text { Stickleback (Gasterosteus } \\
\text { aculeatus) }\end{array}$} & CHORI-213 & 190 & pTARBAC2.1 & $\begin{array}{l}\text { Ensembl and colony filter } \\
\text { screening }\end{array}$ & BPRC-CHORI (pdejong@chori.org) \\
\hline & CHORI-218 & 175 & pTARBAC2.1 & & \\
\hline
\end{tabular}

Strain for Tol2-BAC microinjection. In principle, the BAC construct should be microinjected into fertilized eggs derived from the healthiest zebrafish strain (with the highest survival rate) such as the wild-type strains $T A B$ or $T L$. However, alternative strains may be used to facilitate screening of transgenic carriers or to avoid delays due to breeding in the future. If the aim is to create a BAC transgenic line expressing Gal4, the Tol2-BAC construct can be injected directly into the homozygous UASGFP strain ${ }^{10}$ to select fluorescent-positive-injected embryos/larvae (carrying both BAC: Gal4 and UASGFP). Another useful strain is nacre, a mitfa-recessive mutant lacking melanophore pigmentation ${ }^{57}$, which is transparent and facilitates live imaging of internal tissues.

\section{MATERIALS}

REAGENTS

- Zebrafish (Danio rerio): wild-type strains (TAB or TL) and transgenic $\mathrm{Tg}$ (UAS:GFP) fish ${ }^{10}$ ! CAUTION All animal experiments should adhere to relevant institutional ethics guidelines.

- Aquatic facility with 2- and 12-liter tanks (Aqua Schwarz or equivalent companies)

- Anesthetic (ethyl 3-aminobenzoate methanesulfonate salt (Sigma, cat. no. A5040)

- SW102 bacteria: SW102 ( $m c r A \Delta(m r r-h s d R M S-m c r B C) \Delta l a c X 74$ deoR recAl endA1 araD139 $\Delta$ (ara, leu)7649 galU rspL nupG $\Phi 80 \mathrm{~d} l a c Z \Delta \mathrm{M} 15 \lambda$ cI857 $($ cro-bioA $) \diamond$ tet $\Delta$ galK) harbors a defective $\lambda$-prophage and deletion of the $\Delta g a l K^{45}$ (obtained from NCI-Frederick) (http://web.ncifcrf.gov/research/ brb/recombineeringInformation.aspx)

- BAC clones purchased from BACPAC Resouces Center or ImaGenes (Table 2)

- galK plasmid: pBluescript SK-pEm7-galK ampicillin resistance $(\mathrm{AmpR})^{45}$

(available from NCI-Frederick)

- iTol2 cassette plasmids: pCR8GW-iTol2-amp, pCR8GW-iTol2-kan and pCR8GW-iTol2-galK available from M.L.S. or K.K. on request

(see Supplementary Data for plasmid map and full sequence)

- Kan cassette plasmids: $p B S K-G F P-p A-F R T-k a n-F R T$, $p C R 8 G W$-Gal4FF-pAFRT-kan-FRT, pCR8GW-Gal4-VP16-pA-FRT-kan-FRT, pCR8GW-Cre-pAFRT-kan-FRT available from M.L.S. on request (see Supplementary Data for plasmid map and full sequence)

- Tol2 TP plasmid: zebrafish codon-optimized Tol2 TP, $p C S 2-z T 2 T P$ available from K.K. on request (see Supplementary Data for plasmid map and full sequence)

- Primers for amplifying iTol2 cassettes (Table 4; Choose primer according to the source of the BAC clone (Table 2). Order 50 nmol with PAGE purification (Sigma) and resuspend in $10 \mathrm{mM}$ Tris-Cl, pH 8.5, at $100 \mu \mathrm{M}$.)
- Gene-specific primers for recombineering reporter gene cassettes and primers for confirming homologous recombination (REAGENT SETUP and Table 4; order $50 \mathrm{nmol}$ with PAGE purification for oligos longer than $50 \mathrm{bp}$ and $25 \mathrm{nmol}$ for up to $50 \mathrm{bp}$. Resuspend in $10 \mathrm{mM}$ Tris-Cl, pH 8.5, at $100 \mu \mathrm{M}$.)

- Primers for sequencing reporter genes after recombineering (Table 4; order $25 \mathrm{nmol}$ (Sigma), desalted and resuspend in $10 \mathrm{mM}$ Tris-Cl, pH 8.5, at $100 \mu \mathrm{M})$

- Oligos for adapter-ligation (ADL) PCR (Table 4; order 25 nmol (Sigma), desalted and resuspend in $10 \mathrm{mM}$ Tris- $\mathrm{Cl}, \mathrm{pH} 8.5$, at $100 \mu \mathrm{M})$

- Primers for single-embryo PCR excision assay (Table 4; order $25 \mathrm{nmol}$ (Sigma), desalted and resuspend in $10 \mathrm{mM}$ Tris-Cl, pH 8.5, at $100 \mu \mathrm{M})$

- Plasmid miniprep kit (Qiagen, cat. no. 27106)

- QIAquick gel extraction kit (Qiagen, cat. no. 28706)

- Nucleobond BAC 100 kit (Macherey-Nagel, cat. no. 740579)

- Ethanol (99.7\%)

- Isopropanol (Sigma, cat. no. I9516) ! CAUTION It is very flammable and irritating to eyes. Inhalation may cause dizziness and nausea.

- Phenol-chloroform-isoamyl alcohol mixture 25:24:1 (Sigma, cat. no. 77617) I CAUTION It is toxic by inhalation, ingestion or contact with skin.

- Chloroform (Sigma, cat. no. C0549) ! CAUTION It is carcinogenic. Wear gloves.

- Ammonium chloride (Sigma, cat. no. A9434) ! CAUTION It is harmful if swallowed and can be irritating to eyes.

- Ammonium sulfate (Sigma, cat. no. A4418)

- Calcium chloride (Sigma, cat. no. C1016)

- Methylene blue hydrate (Sigma, cat. no. 28514) I CAUTION It is harmful if swallowed and can be irritating to the eyes, respiratory system and skin.

- Lithium chloride (Sigma, cat. no. 62478)

- Magnesium sulfate heptahydrate (Sigma, cat. no. M1880) 
PROTOCOL

TABLE 4 | Primers and adapter sequences.

\begin{tabular}{|c|c|c|}
\hline Primer name & Sequence $\left(5^{\prime}-3^{\prime}\right)$ & Purpose \\
\hline ptarbac_itol2_fw & $\begin{array}{l}\text { GCGTAAGCGGGGCACATTTCATTACCTCTTTCTCCGCA } \\
\text { CCCGACATAGATCCCTGCTCGAGCCGGGCCCAAGTG }\end{array}$ & $\begin{array}{l}\text { Amplify iTol2 cassette for BAC recombineering into vectors: } \\
\text { pTARBAC2.1 } \\
\text { pBACe3.6 }\end{array}$ \\
\hline ptarBac_itol2_rev & $\begin{array}{l}\text { CGCGGGGCATGACTATTGGCGCGCCGGATCGATCCTT } \\
\text { AATTAAGTCTACTAATTATGATCCTCTAGATCAGATCT }\end{array}$ & (Step 16) \\
\hline pindigobac_itol2_fw & $\begin{array}{l}\text { TTCTCTGTTTTTGTCCGTGGAATGAACAATGGAAGTCC } \\
\text { GAGCTCATCGCTCCCTGCTCGAGCCGGGCCCAAGTG }\end{array}$ & $\begin{array}{l}\text { Amplify iTol2 cassette for BAC recombineering into vectors: } \\
\text { pIndigoBac- } 536 \\
\text { pBeloBAC11 } \\
\text { pCCFOS1 }\end{array}$ \\
\hline pindigobac_itol2_rev & $\begin{array}{l}\text { CCCGCCAACACCCGCTGACGCGAACCCCTTGCGGCCG } \\
\text { CATATTATGATCCTCTAGATCAGATCT }\end{array}$ & (Step 16) \\
\hline geneX_GFP_fw & gccaccatgGTGAGCAAGGGCGAGGAGCTGTTC & $\begin{array}{l}\text { Amplify GFP cassette for BAC recombineering } \\
(\text { Steps } 33 \mathrm{~A}(\mathrm{i}) \text { and } 33 \mathrm{~B}(\mathrm{x}))\end{array}$ \\
\hline geneX_Gal4FF_fw & GCCACCATGAAGCTACTGTCTTCTATCGAAC & $\begin{array}{l}\text { Amplify Gal4FF cassette for BAC recombineering } \\
\text { (Steps } 33 \mathrm{~A}(\mathrm{i}) \text { and } 33 \mathrm{~B}(\mathrm{x}) \text { ) }\end{array}$ \\
\hline geneX_Gal4-VP16_fw & GCCACCATGGTGAAGCTACTGTCTTCTATCGAAC & $\begin{array}{l}\text { Amplify of Gal4VP16 cassette for BAC recombineering } \\
\text { (Steps } 33 \mathrm{~A}(\mathrm{i}) \text { and } 33 \mathrm{~B}(\mathrm{x}) \text { ) }\end{array}$ \\
\hline geneX_Cre_fw & GCCACCATGGCCAATTTACTGACCGTACACC & $\begin{array}{l}\text { Amplify Cre cassette for } B A C \text { recombineering (Steps } 33 A(i) \\
\text { and } 33 B(x) \text { ) }\end{array}$ \\
\hline geneX_frt-kan-rev & $\begin{array}{l}\text {---50-bp_homology_rev_comp---CCGCGT } \\
\text { GTAGGCTGGAGCTGCTTC }\end{array}$ & $\begin{array}{l}\text { Amplify FRT-kan-FRT cassettes for BAC recombineering } \\
(\text { Step } 33 \mathrm{~A}(\mathrm{i}))\end{array}$ \\
\hline geneX_pA-rev & $\begin{array}{l}\text {---50-bp_homology_rev_comp---GGAA } \\
\text { TTCGGACAAACCACAACTAG }\end{array}$ & Amplify cassettes for galK replacement (Step 33B(x)) \\
\hline GFP_seqF & ATGGTGAGCAAGGGCGAGGAGCTG & $\begin{array}{l}\text { Sequencing GFP (Step 33A(xviii) and 33B(xiv)) } \\
\text { Screening F1 fish (Step 50B(ii)) }\end{array}$ \\
\hline Gal4FF_seqF & ATGAAGCTACTGTCTTCTATCGAAC & $\begin{array}{l}\text { Sequencing GalFF (Step 33A(xviii) and 33B(xiv)) } \\
\text { Screening F1 fish (Step 50B(ii)) }\end{array}$ \\
\hline Gal4-VP16_seqF & ATGGTGAAGCTACTGTCTTCTATCG & $\begin{array}{l}\text { Sequencing Gal4-VP16 (Step 33A(xviii) and 33B(xiv)) } \\
\text { Screening F1 fish (Step 50B(ii)) }\end{array}$ \\
\hline Cre_seqF & ATGGCCAATTTACTGACCGTACACC & $\begin{array}{l}\text { Sequencing Cre (Step 33A(xviii) and 33B(xiv)) } \\
\text { Screening F1 fish (Step 50B(ii)) }\end{array}$ \\
\hline pA_seqR & GAATAGGAACTTCCTGCAGGAATTC & $\begin{array}{l}\text { Sequencing Kan cassettes (Step 33A(xviii) and 33B(xiv)) } \\
\text { F1 screening (Step 50B(ii)) }\end{array}$ \\
\hline $\begin{array}{l}\text { geneX_galK_fw } \\
\text { geneX_galK_rev }\end{array}$ & $\begin{array}{l}\text { CCTGTTGACAATTAATCATCGGCA-- } 50- \\
\text { bp_homology_rev_comp---TCAGCACTGTC- } \\
\text { CTGCTCCTT }\end{array}$ & Amplify galK cassette for BAC recombineering (Step 33B(i)) \\
\hline iT2amp-exc168R & GGGCGACACGGAAATGTTGAATACTC & PCR excision assay for iTol2-amp cassette (Step 46) \\
\hline iT2amp-exc168F & GGTCTCGCGGTATCATTGCAGCACTG & PCR excision assay for iTol2-amp cassette (Step 46) \\
\hline iT2galK-exc159F & CACGGTTTGATAATCAATCGCGCAG & PCR excision assay for iTol2-galK cassette (Step 46) \\
\hline iT2galK-exc922R & CCGTGCCGCAAATTGACACTCTGG & PCR excision assay for iTol2-galK cassette (Step 46) \\
\hline ALS & $\begin{array}{l}\text { CTAATACGACTCACTATAGGGCTCGAGCGGCCGCGG } \\
\text { GGGCAGGT }\end{array}$ & ADL-PCR adapter (see REAGENTS) \\
\hline
\end{tabular}


TABLE 4 | Primers and adapter sequences (continued).

\begin{tabular}{lll}
\hline Primer name & Sequence $\left(\mathbf{5}^{\prime} \mathbf{- 3}^{\prime}\right)$ & Purpose \\
\hline ASS(GATC) & GATCACCTGCCCCCGCTT & ADL-PCR adapter (see REAGENTS and Step 53) \\
ASS(CTAG) & CTAGACCTGCCCCCGCTT & ADL-PCR adapter (see REAGENTS and Step 53) \\
Ap1 & GGATCCTAATACGACTCACTATAGGG & First round in ADL-PCR (Step 54) \\
175L-out & TTTTTGACTGTAAATAAAATTG & First round in ADL-PCR (Step 54) \\
150R-out & AATACTCAAGTACAATTTTA & First round in ADL-PCR (Step 54) \\
Ap2 & CACTATAGGGCTCGAGCGG & Second round in ADL-PCR (Step 56) \\
150L-out & GAGTAAAAAGTACTTTTTTTTCT & Second round in ADL-PCR (Step 56) \\
100R-out & AGATTCTAGCCAGATACT & $\begin{array}{l}\text { Second round in ADL-PCR, sequencing ADL-PCR products } \\
\text { (Steps 56 and 59) }\end{array}$ \\
100L-out & AGTATTGATTTTTAATTGTA & Sequencing ADL-PCR products (Steps 59) \\
\hline
\end{tabular}

'50-bp homology' refers to target gene $X$ in the BAC; 'rev_comp' refers to the reverse-complement DNA sequence. Lowercase and italic in 'Sequence' column marks nucleotides not present in the template DNA.

- Potassium chloride (Sigma, cat. nos. P9333 and RNase-free P9541)

- Potassium phosphate, monobasic (Sigma, cat. no. P5655)

- Sodium chloride (Sigma, cat. no. S7653)

- Sodium phosphate, dibasic (Sigma, cat. no. S7907)

- Ferrous sulfate heptahydrate (Sigma, cat. no. F8048)! CAUTION It is

harmful if swallowed.

- Potassium hydroxide (Sigma, cat. no. P5958) ! CAUTION It is toxic and highly corrosive.

- D-biotin (Sigma, cat. no. 47868)

- Glycerol, min 99\% (Sigma, cat. no. G6279)

- D-(+)-galactose (Sigma, cat. no. G0750)

- 2-Deoxy-D-galactose (Sigma, cat. no. 31050)

- L-Leucine (Sigma, cat. no. L8912)

- Ampicillin sodium salt, cell culture tested (Sigma, cat. no. A0166)

! CAUTION Inhalation and skin contact may cause allergic reactions.

- Chloramphenicol (Sigma, cat. no. C-0378) ! CAUTION It is carcinogenic.

- Kanamycin sulfate (Invitrogen, cat. no. 11815)

- Tetracycline hydrochloride (Sigma, cat. no. T3383)! CAUTION It is irritating to the eyes, respiratory system and skin.

- Spectinomycin dihydrochloride pentahydrate (Sigma, cat. no. 85555)

- Minimal salts, M9

- Sterile $\mathrm{H}_{2} \mathrm{O}$ purified, deionized and $0.22 \mu \mathrm{m}$ filtered (Milli-Q, Millipore)

- Bacto-tryptone (Difco, cat. no. 0123-01-1)

- Bacto-yeast extract (Difco, cat. no. 0127-05-3)

- Bacto-agar (Difco, cat. no. 0140-01)

- MacConkey agar base (Difco, cat. no. 281810)

- Agarose (Sigma, cat. no. A5093)

- Tris base (Sigma, cat. no. T1503)

- Glacial acetic acid (Sigma, cat. no. 320099) ! CAUTION It is flammable and highly corrosive.

- Ethylenediaminetetraacetic acid disodium salt dihydrate (EDTA;

Sigma, cat. no. E5134)

- Ethidium bromide solution, $10 \mathrm{mg} \mathrm{ml}^{-1}$ (Sigma, cat. no. E1510)! CAUTION

It is toxic by inhalation and it causes damage to DNA.

- BlueJuice gel loading buffer (10×; Invitrogen, cat. no. 10816-015)

- DNA ladder (1 Kb; Invitrogen, cat. no. 15615-016)

- $\lambda$ DNA/HindIII fragments (Invitrogen, cat. no. 15612-013)

- mMESSAGE mMACHINE SP6 kit (Ambion, cat. no. 1340)

- Mini Quick Spin RNA columns (Roche, cat. no. 11814427001)

- RNA Ladder (0.5-10 Kb; Invitrogen, cat. no. 15623-200)

- NorthernMax kit for running denaturing RNA gel (Invitrogen, cat. no. AM1940)! CAUTION Loading dye, gel and buffer contain formaldehyde. It is toxic by inhalation, ingestion and skin contact. It is carcinogenic.
- Nuclease-free water (Invitrogen, cat. no. AM9930)

- Phenol red sodium salt (Sigma, cat. no. 114537) ! CAUTION It is irritating to the eyes, respiratory system and skin. Wear gloves when handling it.

- Proteinase K (Sigma, cat. no. P2308) ! CAUTION It is irritating to the eyes, respiratory system and skin.

- Sodium dodecyl sulfate (Invitrogen, cat. no. 15525-017)

- Sodium acetate buffer solution, pH 5.2 (3M; Sigma, cat. no. S7899)

- Expand high-fidelity PCR system or a similar kit with proofreading ability (Roche, cat. no. 11681834001)

- GoTaq Flexi DNA polymerase for quick PCR screening (Promega, cat. no. M8305)

- PCR nucleotide mix (dNTPs), 10 mM each (Roche, cat. no. 11581295001)

- Restriction enzymes (AluI, DpnI, MboI, BglII, NotI, SalI, SpeI, XbaI and XhoI) and T4 DNA ligase (Takara and NEB)

- DNA sequencing, BigDye terminator v3.1 cycle sequencing kit; $5 \times$ sequencing buffer for diluting enzyme; HiDi formamide (Applied Biosystems)

EQUIPMENT

- Thermal cycler and accessories for PCR (MyCycler, Bio-Rad)

- DNA electrophoresis system, submerged horizontal (Sub-Cell Systems, Bio-Rad)

- Spectrophotometer for determining DNA concentration (NanoDrop, Thermo Scientific)

- Spectrophotometer for measuring bacterial optical density at $600 \mathrm{~nm}$ $\left(\mathrm{OD}_{600}\right)$ (DU640, Beckman)

- Benchtop refrigerated centrifuge, capacity 0.5-50 ml (Eppendorf, cat. no. 5805000017, model 5804R, Eppendorf)

- Benchtop centrifuge (Eppendorf, cat. no. 5424000410, model 5418)

- Constant temperature incubators set at $32^{\circ} \mathrm{C}$ and $37^{\circ} \mathrm{C}$ (Medinor, cat. no. 15110)

- Constant temperature dry heat blocks set at $42-95^{\circ} \mathrm{C}$ (Medinor, cat. no. D1105)

- Shaking water bath, 210 r.p.m, with temperature control (Grant)

- Sterile Petri dishes, $92 \times 16$ mm (Sarstedt, cat. no. 82.1472.001)

- Sterile Petri dishes for microinjection, $60 \times 15 \mathrm{~mm}$ (Falcon, cat. no. 351007)

- Sterile tubes for PCR (0.2 ml; VWR, cat. no. 732-0547)

- Eight-strip PCR tube $(0.2 \mathrm{ml})$ and flat 8-cap strips for PCR (Bio-Rad, cat. nos. TLS-0801, TCS-0803)

- PCR tube with flat cap (0.5 ml; VWR, cat. no. 732-0675)

- Sterilized Eppendorf tubes, 3810 (1.5 ml; Eppendorf, cat. no. 700-5239)

- Sterile tubes for storage of bacterial stocks ( $2 \mathrm{ml}$; Sarstedt, cat. no. 72.694.406)

- SafeSeal micro tubes (2 ml; Sarstedt, cat. no. 72.695)

- Bacterial round-bottom tubes with cap (14 ml; BD Biosciences, cat. no. 352059) 


\section{Box 1 | Preparation of SW102 electrocompetent cells TIMING 1 d}

1. Streak out glycerol stock (from $-80^{\circ} \mathrm{C}$ freezer) on an LB plate containing tetracycline $\left(20 \mu \mathrm{g} \mathrm{ml} \mathrm{m}^{-1}\right)$ to obtain single colonies.

2. Grow SW102 cells for $16-18 \mathrm{~h}$ at $32{ }^{\circ} \mathrm{C}$.

3. Pick a single colony and grow it overnight in $5 \mathrm{ml}$ of LB-tetracycline medium.

4. The next morning, dilute $2.5 \mathrm{ml}$ of culture into $500 \mathrm{ml}$ of LB-tetracycline.

5. Grow culture at $32{ }^{\circ} \mathrm{C}$ until the $0 \mathrm{D}_{600}$ reaches $0.6(\sim 3-4 \mathrm{~h})$.

6. Transfer to $2250-\mathrm{ml}$ prechilled centrifuge tubes. Chill the cells for $20 \mathrm{~min}$ on an ice-water bath.

7. Spin at $4,500 \mathrm{~g}$ for $15 \mathrm{~min}$ at $4^{\circ} \mathrm{C}$.

8. Remove the supernatant from each tube and resuspend in $200 \mathrm{ml}$ of ice-cold sterile water.

9. Spin at $4,500 \mathrm{~g}$ for $15 \mathrm{~min}$ at $4^{\circ} \mathrm{C}$.

10. Remove the supernatant from each tube and resuspend in $200 \mathrm{ml}$ of ice-cold sterile water.

11. Spin at $4,500 \mathrm{~g}$ for $15 \mathrm{~min}$ at $4{ }^{\circ} \mathrm{C}$.

12. Remove the supernatant from each tube and resuspend in $5 \mathrm{ml}$ of ice-cold sterile $10 \%$ (wt/vol) glycerol.

13. Transfer SW102 cells $(10 \mathrm{ml})$ to a prechilled $15-\mathrm{ml}$ Falcon tube.

14. Spin at $4,500 \mathrm{~g}$ for $20 \mathrm{~min}$ at $4{ }^{\circ} \mathrm{C}$.

15. Decant all supernatant and resuspend in a final volume of $1 \mathrm{ml}$ of ice-cold sterile $10 \%$ (wt/vol) glycerol.

16. Measure the $\mathrm{OD}_{600}$ for a $1: 100$ dilution of cells. $\mathrm{An} \mathrm{OD}_{600}$ of 3.75 corresponds to $\sim 2.5 \times 10^{10}$ cells per ml, which is an optimal density for electrocompetent cells.

17. Dispense into $2050-\mu \mathrm{l}$ aliquots and store immediately at $-80^{\circ} \mathrm{C}$. These cells should be enough for $\sim 40$ experiments (25 $\mu$ l per electroporation).

- Falcon tubes (15 ml; VWR, cat. no. 734-0451)

- Falcon tubes (50 ml; VWR, cat. no. 734-0448)

- Duran Erlenmeyer narrow-neck flasks ( 50 ml; Sigma, cat. no. Z232785)

- Gilson Pipetman set and filtered tips (VWR, cat. nos. 732-2225, 732-2236,732-2207)

- Hand-held electric Pipetman for 1-10 ml volume (Medinor P2000)

- Electroporation machine, MicroPulser (Bio-Rad, cat. no. 165-2100)

- GenePulser electroporation cuvettes, 0.1-cm gap (Bio-Rad, cat. no. 1652089)

- Plastic mating boxes, $24.5 \times 15 \times 16.5 \mathrm{~cm}$ (Spawn Box 3, Aqua Schwarz)

- Glass capillaries for microinjection (GC-1, Narishige)

- KIMAX-51 capillaries, 0.8-1.10 × 100 mm (Sigma, cat. no. KIM-34502-99-20EA)

- Microloader tips for loading glass capillaries (Eppendorf,

cat. no. 5242 956.003)

- Micropipette capillary puller (Sutter Instruments, cat. no. P-87)

- Dow Corning Sylgard 184 elastomer kit (VWR, cat. no. 634I65S)

- Dumont No. 5 forceps, $0.05 \mathrm{~mm} \times 0.01 \mathrm{~mm}$ (Fine Science Tools, cat. no. 11254-20)

- Pressure microinjection system with pipette holder (Applied Scientific Instrumentation, MPPI-3)

- Dissecting stereomicroscope (SMZ645, Nikon)

- Fluorescent stereomicroscope equipped with GFP/RFP filters

(MZFLIII, Leica)

- Computer with web browser and other software for analysis of genomic

DNA sequences and primer design (DNA Strider, ApE Plasmid Editor v2.0.30 and Amplify $3 \times$ )

- Capillary electrophoresis instrument (e.g., Applied Biosystems

3130xl or similar)

\section{REAGENT SETUP}

Zebrafish Adult fish are maintained at a density of 10-30 fish per 12-liter tank with a 14 -h light: 10 -h dark cycle at $28.5^{\circ} \mathrm{C}$. I CAUTION All work must comply with relevant ethical guidelines on animal experiments.

Chloramphenicol Chloramphenicol is prepared by dissolving $12.5 \mathrm{mg} \mathrm{ml}^{-1}$ in $99.7 \%$ ( vol/vol) ethanol. Store at $-20^{\circ} \mathrm{C}$ in $1-\mathrm{ml}$ aliquots for up to 1 year. I CAUTION Wear gloves and a dust mask when handling powder and solution. Kanamycin Kanamycin is prepared by dissolving $25 \mathrm{mg} \mathrm{ml}^{-1}$ in $\mathrm{H}_{2} \mathrm{O}$. Store at $-20^{\circ} \mathrm{C}$ in $1-\mathrm{ml}$ aliquots for up to 1 year.

Ampicillin Ampicillin is prepared by dissolving $50 \mathrm{mg} \mathrm{ml}^{-1}$ in $\mathrm{H}_{2} \mathrm{O}$. Store at $-20^{\circ} \mathrm{C}$ in $1-\mathrm{ml}$ aliquots for up to 1 year.

Tetracycline Tetracycline is prepared by dissolving $12.5 \mathrm{mg} \mathrm{ml}^{-1}$ in $50 \%$ (vol/vol) ethanol. Store at $-20{ }^{\circ} \mathrm{C}$ in $1-\mathrm{ml}$ aliquots for up to 1 year.

Protect from light.
Spectinomycin Spectinomycin is prepared by dissolving $50 \mathrm{mg} \mathrm{ml}^{-1}$ in $\mathrm{H}_{2} \mathrm{O}$. Store at $-20^{\circ} \mathrm{C}$ in $1-\mathrm{ml}$ aliquots for up to 1 year.

LB medium Mix $10 \mathrm{~g}$ of Bacto-tryptone, $5 \mathrm{~g}$ Bacto-yeast and $5 \mathrm{~g}$ of

$\mathrm{NaCl}$ in 1 liter of distilled $\mathrm{H}_{2} \mathrm{O}$. Autoclave and store at $25^{\circ} \mathrm{C}$ for up to 6 months.

LB-agar plates Sterile Petri dishes $(92 \mathrm{~mm} \times 16 \mathrm{~mm}$ ) containing $1 \%$ (wt/vol) Bacto-agar with one or several antibiotics: chloramphenicol, $12.5 \mu \mathrm{g} \mathrm{ml}^{-1}$; kanamycin, $25 \mu \mathrm{g} \mathrm{ml}^{-1}$; ampicillin, $50 \mu \mathrm{g} \mathrm{ml}^{-1}$; and tetracycline, $12.5 \mu \mathrm{g} \mathrm{ml}^{-1}$. Store at $4{ }^{\circ} \mathrm{C}$ for up to 2 months.

SW102 electrocompetent cells Streak bacteria onto an LB-tetracycline plate to obtain single colonies. Pick a single colony and grow overnight in $5 \mathrm{ml}$ of LB-tetracycline at $32^{\circ} \mathrm{C}$, with shaking at 210 r.p.m. Prepare a glycerol stock by combining $500 \mu \mathrm{l}$ of this culture and $500 \mu \mathrm{l}$ of $30 \%$ (wt/vol) glycerol in a 2-ml sterile tube; store at $-80^{\circ} \mathrm{C}$ for up to 1 year. Starting from this stock, prepare electrocompetent cells as described in Box 1 .

M9 medium Mix $6 \mathrm{~g}$ of $\mathrm{Na}_{2} \mathrm{HPO}_{4}, 3 \mathrm{~g}$ of $\mathrm{KH}_{2} \mathrm{PO}_{4}, 1 \mathrm{~g}$ of $\mathrm{NH}_{4} \mathrm{Cl}$ and $0.5 \mathrm{~g}$ of $\mathrm{NaCl}$ in 1 liter of sterile $\mathrm{H}_{2} \mathrm{O}$. Autoclave and store at $25^{\circ} \mathrm{C}$ in a glass bottle for up to 1 year.

M63 medium (5×) Mix $10 \mathrm{~g}$ of $\left(\mathrm{NH}_{4}\right)_{2} \mathrm{SO}_{4}, 68 \mathrm{~g}$ of $\mathrm{KH}_{2} \mathrm{PO}_{4}$ and $2.5 \mathrm{mg}$ of $\mathrm{FeSO}_{4} \cdot 7 \mathrm{H}_{2} \mathrm{O}$ in 1 liter of sterile $\mathrm{H}_{2} \mathrm{O}$; adjust $\mathrm{pH}$ to 7 with $\mathrm{KOH}$. Autoclave and store at $25^{\circ} \mathrm{C}$ in a glass bottle for up to 1 year.

M63 minimal medium plates Dissolve $15 \mathrm{~g}$ Bacto-agar in $800 \mathrm{ml}$ of distilled $\mathrm{H}_{2} \mathrm{O}$, sterilize and then add $200 \mathrm{ml}$ of $5 \times \mathrm{M} 63$ medium, $1 \mathrm{ml}$ of $1 \mathrm{M}$ $\mathrm{MgSO}_{4} \cdot 7 \mathrm{H}_{2} \mathrm{O}, 10 \mathrm{ml}$ of $20 \%$ (wt/vol) galactose, $5 \mathrm{ml}$ of $0.2 \mathrm{mg} \mathrm{ml}^{-1}$ biotin $\left(0.2 \mu \mathrm{m}\right.$ sterile filtered), $4.5 \mathrm{ml}$ of $10 \mathrm{mg} \mathrm{ml}^{-1}$ leucine (heated and $0.2-\mu \mathrm{m}$ sterile filtered) and antibiotic. Pour into 40 92-mm Petri dishes and store at $4{ }^{\circ} \mathrm{C}$ for up to 2 months.

DOG minimal medium plates Dissolve $15 \mathrm{~g}$ Bacto-agar in $800 \mathrm{ml}$ of distilled $\mathrm{H}_{2} \mathrm{O}$, sterilize, and then add $200 \mathrm{ml}$ of $5 \times \mathrm{M} 63$ medium, $1 \mathrm{ml}$ of $1 \mathrm{M}$ $\mathrm{MgSO}_{4} \cdot 7 \mathrm{H}_{2} \mathrm{O}, 10 \mathrm{ml}$ of $20 \%$ (wt/vol) glycerol, $10 \mathrm{ml}$ of $20 \%$ (wt/vol) DOG, $5 \mathrm{ml}$ of $0.2 \mathrm{mg} \mathrm{ml}^{-1}$ biotin, $4.5 \mathrm{ml}$ of $10 \mathrm{mg} \mathrm{ml}^{-1}$ leucine and antibiotic. Pour into 40 92-mm Petri dishes and store at $4^{\circ} \mathrm{C}$ for up to 2 months. MacConkey agar plates Dissolve $5 \mathrm{~g}$ of agar in $500 \mathrm{ml}$ of distilled $\mathrm{H}_{2} \mathrm{O}, 5 \mathrm{ml}$ of $20 \%$ (wt/vol) galactose, sterilize, cool and add antibiotic. Pour into $\sim 30$ 92-mm Petri dishes and store at $4{ }^{\circ} \mathrm{C}$ for up to 2 months.

E3 medium Mix $20 \mathrm{ml}$ of $5 \mathrm{M} \mathrm{NaCl}, 3.4 \mathrm{ml}$ of $1 \mathrm{M} \mathrm{KCl}, 6.6 \mathrm{ml}$ of $1 \mathrm{M}$ $\mathrm{CaCal}_{2}, 6.6 \mathrm{ml}$ of $1 \mathrm{M} \mathrm{MgSO}_{4}$ and $2 \mathrm{ml}$ of $0.05 \%$ (wt/vol; optional) methylene blue in 20 liters of sterile $\mathrm{H}_{2} \mathrm{O}$. Adjust $\mathrm{pH}$ to 7 . Store at $25^{\circ} \mathrm{C}$ for up to 2 months.

TE buffer Combine $10 \mathrm{mM}$ Tris, $\mathrm{pH} 8.0$, and $1 \mathrm{mM}$ EDTA. Store at $25^{\circ} \mathrm{C}$ for up to 6 months. 
Tricaine solution Dissolve $20 \mathrm{mg}$ of Tricaine in $100 \mathrm{ml}$ of E3 medium. Freshly prepare on the day of use.

Phenol red solution Dissolve $2.5 \%$ of ( $\mathrm{wt} / \mathrm{vol}$ ) phenol red in nuclease-free water. Store at $-20^{\circ} \mathrm{C}$ in $1-\mathrm{ml}$ aliquots for up to 1 year.

Embryo lysis buffer Mix $10 \mathrm{mM}$ Tris, $10 \mathrm{mM}$ EDTA and $200 \mu \mathrm{g} \mathrm{ml}^{-1}$ proteinase K. Freshly prepare on the day of use.

Genomic DNA extraction buffer Combine $10 \mathrm{mM}$ Tris-HCl, $\mathrm{pH} 8.2$; $10 \mathrm{mM}$ EDTA; $200 \mathrm{mM} \mathrm{NaCl} ; 0.5 \%$ (wt/vol) SDS; and $200 \mu \mathrm{g} \mathrm{ml}^{-1}$

proteinase K. Freshly prepare on the day of use.

TAE (10 $\times)$ Mix $48.4 \mathrm{~g}$ of Tris base, $11.42 \mathrm{ml}$ of glacial acetic acid and $3.72 \mathrm{~g}$ of EDTA in 1 liter of $\mathrm{H}_{2} \mathrm{O}$. Store at $25^{\circ} \mathrm{C}$ for up to 6 months.

Gene-specific primers For recombineering, design 82-90-mer singlestranded PCR oligos to amplify galK, GFP, Gal4FF, Gal4VP16 or Cre and the kan recombineering cassettes (Fig. 2b) using the sequences listed in Table 4. Also design 25-30-mer oligos to confirm the recombination events by PCR, by choosing sequences that are approximately $50-100$ bp away from the BAC target site. To replace an open reading frame in the BAC, one cassette primer should contain sequence annealing to at least 50 bp surrounding and upstream of the expected translation start, whereas the second primer should contain sequence annealing to an exon/intron at least $500 \mathrm{bp}$ downstream from the first primer. In general, primers should have a melting temperature of $>55{ }^{\circ} \mathrm{C}$ and a minimum of a 50-bp homology to the BAC sequence. Free online software such as Amplify $3 \times$ (http://engels.genetics.wisc.edu/amplify/) can be used for designing the primers.

ADL-PCR adapters Mix the following in 1.5-ml Eppendorf tubes: $50 \mu \mathrm{l}$ of $100 \mu \mathrm{M}$ ASS(GATC) or ASS(CTAG), $2 \mu \mathrm{l}$ of T4 polynucleotide kinase, $10 \mu \mathrm{l}$ of $10 \times$ buffer, $10 \mu \mathrm{l}$ of $10 \mathrm{mM}$ ATP and $28 \mu \mathrm{l}$ of sterile $\mathrm{H}_{2} \mathrm{O}$. Incubate at $37^{\circ} \mathrm{C}$ for $1 \mathrm{~h}$ and at $75^{\circ} \mathrm{C}$ for $5 \mathrm{~min}$, add $50 \mu \mathrm{l}$ of $100 \mu \mathrm{M} \mathrm{ALS}$, incubate at $94^{\circ} \mathrm{C}$ for $1 \mathrm{~min}$ and at $60^{\circ} \mathrm{C}$ for $10 \mathrm{~min}$, cool down to $25^{\circ} \mathrm{C}$, precipitate with $99.7 \%$ ( vol $/ \mathrm{vol}$ ) ethanol, spin down for $10 \mathrm{~min}$ at $16,000 \mathrm{~g}$, wash with $70 \%$ ( $\mathrm{vol} / \mathrm{vol}$ ) ethanol and resuspend in a final volume of $50 \mu \mathrm{l}$ of $10 \mathrm{mM}$ Tris-Cl, $\mathrm{pH} 8.5$. Store at $-20^{\circ} \mathrm{C}$ for up to 6 months.

\section{EQUIPMENT SETUP}

Embryo microinjection dish Fill the lid of a Petri dish $(60 \times 15 \mathrm{~mm})$ with enough Sylgard (prepared according to the manufacturer's instructions) just to cover four glass capillaries (Kimax-51, 3.5 cm long, outer diameter $1 \mathrm{~mm}$ ) placed at equal distance and parallel to each other. Alternatively, prepare a $1 \%$ (wt/vol) agarose ramp with a glass plate as described previously ${ }^{53}$.

Microinjection capillaries Pull glass capillaries (Narishige GC-1) with a Micropipette puller (e.g., Sutter P-87, heat $=645$, pull $=163$, vel $=145$ and time $=50)$ to obtain a long and fine needle; break with fine forceps to create a $\sim 2-3-\mu \mathrm{m}$ tip. Prepare immediately before microinjection.

Microinjection setup Set up the ASI MPPI-3 pressure injection system with foot pedal external trigger according to the manufacturer's instructions. A source of compressed air with at least $20 \mathrm{psi}$ is required.

\section{PROCEDURE}

\section{Identification of BAC clones $\bigcirc$ TIMING $1 \mathrm{~d}$}

1| Open the Ensembl Zv9 (http://www.ensembl.org/Danio_rerio/Info/Index) or ZFIN (http://zfin.org/cgi-perl/gbrowse/current/) websites in your web browser and type the gene name or perform a search using BLAST options.

2| In Ensembl, open the 'Gene' page of your gene of interest and click on 'Location' to open 'chromosome view'. Select 'Configure this page' from the left panel. This will open a new window inside the page. In this window, click '0ther DNA alignments' under the Main panel. Enable 'BAC ends' and 'FOS ends' to see genomic clones in your region of interest.

3| Locate 'BAC ends' that appear as blue squares within the expanded genomic region. Click on those BACs (unfilled rectangles flanked by the blue squares) whose ends cover the gene of interest to obtain the Ensembl prefix (e.g., zC175D15.za).

It is preferable to use a BAC clone in which the gene of interest is located in the middle of the BAC, as it is more likely that such a clone will contain most, if not all, of the cis-regulatory elements required for the full and correct expression pattern of that gene.

4| Align the entire coding sequence of the gene with the contig, scaffold or BAC clone sequence to identify unambiguously all exons, introns and the first methionine. In some cases, you can use the NCBI Genome Project browser to identify clones or 'trace' sequences that may not have been annotated yet in Ensembl. We recommend using computerized DNA analysis programs such as DNA Strider to carry out sequence alignments.

5| Order the BAC, PAC or fosmid (FOS) clones. To order the clones, you must find the original library clone name and number corresponding to the Ensembl prefix obtained in Step 3 above (see also Table 2). For example, a clone with the name zC175D15 in Ensembl belongs to the CHORI-211 library (prefix zC), clone number 175D15. If your gene is larger than $100 \mathrm{~kb}$ and there are several BAC or FOS clones that cover the region of interest, order two clones that overlap.

$\triangle$ CRITICAL STEP Pay careful attention to the correct identification of the gene and BAC clones, particularly if your genomic region has not been well annotated.

$\triangle$ CRITICAL STEP If possible, avoid excessively large BACs (>200 kb), as these are more prone to breakage during BAC DNA preparation and microinjection steps. In addition, keep in mind that the presence of unusually high GC-rich sequences or many repeats might lead to toxicity that could compromise recombineering or transgenesis steps.

\section{Preparation of BAC-containing competent cells $\bigcirc$ TIMING $4 \mathrm{~d}$}

6| Streak a small amount of bacteria from the BAC agar stab shipped by the supplier to a fresh LB-chloramphenicol agar plate to obtain single colonies. 


\section{Box 2 | BAC DNA miniprep protocol $\bigcirc$ TIMING $2 \mathrm{~h}$}

1. Grow bacteria harboring the $\mathrm{BAC}$ in a $15-\mathrm{ml}$ Falcon tube with $5 \mathrm{ml}$ of LB-chloramphenicol medium overnight at $32{ }^{\circ} \mathrm{C}$ with shaking at 200 r.p.m.

2. Collect the bacteria by centrifugation at $2,500 \mathrm{~g}$ for $5 \mathrm{~min}$.

3. Remove the supernatant and dissolve the pellet in $250 \mu \mathrm{l}$ of buffer P1 (Qiagen miniprep kit); transfer to a 1.5-ml Eppendorf tube.

4. Add $250 \mu$ of P2 buffer to the suspension. Mix gently by inverting and incubate for 5 min at room temperature.

5. Add $250 \mu \mathrm{l}$ of N3 buffer to the suspension. Mix gently by inverting and incubate for 5 min on ice.

6. Clear the supernatant by two rounds of centrifugation at $16,000 \mathrm{~g}$ for $5 \mathrm{~min}$. Each time, the supernatant is transferred to a new tube.

7. Transfer the supernatant to 2-ml SafeSeal microcentrifuge tube.

8. Add $750 \mu \mathrm{l}$ of isopropanol to the eluted sample to precipitate the BAC DNA. Mix gently and incubate on ice for 10 min, and then centrifuge for $10 \mathrm{~min}$ at $16,000 \mathrm{~g}$. Wash the pellet in $70 \%$ ( $\mathrm{vol} / \mathrm{vol})$ ethanol and then air-dry.

9. Dissolve the pellet in $50 \mu \mathrm{l}$ of $10 \mathrm{mM}$ Tris-Cl, pH 8.5 or sterile water. Approximately 1-1.5 $\mu \mathrm{g}$ of DNA is obtained. Use the sample for restriction enzyme analysis, sequencing and transformation of SW102 bacterial cells.

7| Pick two individual colonies using a plastic filtered tip on a P20 pipette and transfer them into 14-ml round-bottom tubes containing $5 \mathrm{ml}$ of LB-chloramphenicol. Grow overnight at $32{ }^{\circ} \mathrm{C}$ with shaking at 210 r.p.m.

8| The next day, prepare BAC DNA from the bacterial cultures using a quick miniprep protocol (Box 2) and ensure that DNA is resuspended in $50 \mu \mathrm{l}$ of sterile water. Remember to retain $500 \mu \mathrm{l}$ of the culture to prepare a glycerol stock by mixing $500 \mu \mathrm{l}$ of culture and $500 \mu \mathrm{l}$ of sterile $30 \%$ (wt/vol) glycerol; store at $-80^{\circ} \mathrm{C}$ indefinitely.

9| Digest BAC plasmid DNA to check its size and integrity as follows:

\begin{tabular}{lcl} 
Component & Amount $(\mu l)$ & Final \\
\hline BAC plasmid DNA & 25 & Unknown \\
Takara $(10 \times) \mathrm{H}$ or M buffer & 4 & $1 \times$ \\
SalI $\left(20 \cup \mu \mathrm{L}^{-1}\right)$ or SpeI $\left(10 \cup \mu \mathrm{L}^{-1}\right)$ & 1 & Variable \\
Sterile water & To 40 & \\
\hline
\end{tabular}

10| Add $4 \mu \mathrm{l}$ of gel loading dye (10x BlueJuice) to the reaction and run the sample in a $0.8 \%$ (wt/vol) agarose gel. Run the gel for $\sim 1 \mathrm{~h}$ at $90 \mathrm{~V}$. Photograph the gel under UV light $(400 \mathrm{~nm}-315 \mathrm{~nm})$ and observe the digestion pattern. Compare the observed pattern with the one expected from the available genomic DNA sequence using the free web tool at http://tools. neb.com/NEBcutter2/.

$\triangle$ CRITICAL STEP If unexpected band sizes are observed upon restriction digestion, we recommend repeating DNA isolation and rechecking several more colonies before proceeding.

11| Thaw SW102 electrocompetent cells stored as $25-\mu \mathrm{l}$ aliquots at $-80^{\circ} \mathrm{C}$. Place cells on ice (always keep close to $0^{\circ} \mathrm{C}$ ).

12| Transfer $25 \mu \mathrm{l}$ of SW102 cells to a prechilled 1.5-ml tube. Add 1-5 $\mu$ (approximately 200-500 ng) of BAC DNA to the cells, mix gently by tapping and incubate for 5-10 min on ice.

13| Transfer the cells to a prechilled 0.1-cm gap cuvette and keep it on ice. Quickly transfer the cuvette to the electroporation holder and apply $1.8 \mathrm{kV}, 25 \mu \mathrm{F}$ and $200 \Omega$ resistance, with a time constant of $5 \mathrm{msec}$, by pressing the pulse button under the Ec1 setting in the BioRad MicroPulser electroporator.

! CAUTION Ensure that the outside of the cuvette is dry before applying a current.

$\Delta$ CRITICAL STEP Ensure that bacteria are quickly transferred from ice to the electroporation holder. Cells must be cold during electroporation.

? TROUBLESHOOTING

14| Immediately add $1 \mathrm{~mL}$ of LB to the cuvette, pipette cells up and down and transfer to a 14-ml round-bottom tube. Incubate at $32{ }^{\circ} \mathrm{C}$ for $1 \mathrm{~h}$ with shaking at 210 r.p.m. 
15| Transfer cells to a 1.5-ml Eppendorf tube. Spin at 14,000 g for $30 \mathrm{~s}$. Remove most of the supernatant, leaving $100 \mu \mathrm{l}$ behind. Resuspend by tapping a few times (do not vortex). Spread the transformed bacteria evenly on LB-chloramphenicol agar plates (as the BAC clone carries the $C m R$ gene). Incubate the plates overnight at $32^{\circ} \mathrm{C}$.

\section{Recombineering the $i T o l 2$ cassette into the BAC plasmid $\bigcirc$ TIMING $2 \mathrm{~d}$}

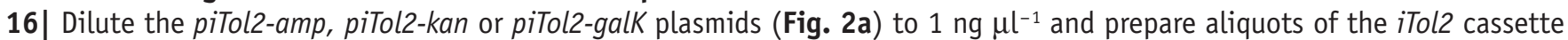
primers at $50 \mu \mathrm{M}$ in $\mathrm{H}_{2} \mathrm{O}$. For CHORI-211 and CHORI-73 BAC libraries, use primers ptarbac_itol2_fw and ptarbac_itol2_rev; for CHORI-1073, DanioKey and DanioKey Pilot, use primers pindigobac_itol2_fw and pindigobac_itol2_rev (Table 2 and for further information).

17| Combine the following reagents for a $100-\mu \mathrm{L}$ PCR in a $0.2-\mathrm{ml}$ sterile tube:

\begin{tabular}{lcc}
\hline Component & Amount $(\mu \mathrm{l})$ & Final \\
\hline piTol2-amp plasmid DNA $\left(1 \mathrm{ng} \mu^{-1}\right)$ & 1 & $1 \mathrm{ng}$ \\
Expand high-fidelity buffer $(10 \times)$ with $\mathrm{MgCl}_{2}$ & 10 & $1 \times$ \\
$10 \mathrm{mM}$ dNTP mixture $(10 \mathrm{mM})$ & 2 & $0.3 \mathrm{mM}$ \\
Primer itol2_fw $(50 \mu \mathrm{M})$ & 2 & $1 \mu \mathrm{M}$ \\
Primer itol2_rev $(50 \mu \mathrm{M})$ & 2 & $1 \mu \mathrm{M}$ \\
Expand high-fidelity enzyme $\left(3.5 \mathrm{U} \mu \mathrm{l}^{-1}\right)$ & 1 & $3.5 \mathrm{U}$ \\
Nuclease-free water & To 100 & \\
\hline
\end{tabular}

18| Run the PCR with the following conditions optimized for Roche PCR enzymes on a Bio-Rad machine (MyCycler):

\begin{tabular}{llll}
\hline Cycle number & Denature & Anneal & Extend \\
\hline 1 & $94^{\circ} \mathrm{C}, 2 \mathrm{~min}$ & & \\
$2-30$ & $94^{\circ} \mathrm{C}, 30 \mathrm{~s}$ & $58{ }^{\circ} \mathrm{C}, 30 \mathrm{~s}$ & $72{ }^{\circ} \mathrm{C}, 2 \mathrm{~min}$ \\
31 & & & $72{ }^{\circ} \mathrm{C}, 5 \mathrm{~min}$ \\
\hline
\end{tabular}

19| Remove the template plasmid DNA by adding it to $2 \mu \mathrm{l}$ of DpnI to the PCR product and incubating it at $37{ }^{\circ} \mathrm{C}$ for $6-8 \mathrm{~h}$. $\triangle$ CRITICAL STEP It is essential to ensure complete digestion of the plasmid DNA template by DpnI. Otherwise, many falsepositive colonies will arise in Step 32.

20| Purify the PCR product by adding $10 \mu \mathrm{l}$ of $10 \times$ BlueJuice, split the sample and load $50 \mu$ leach into two wells in a $1 \%$ (wt/vol) agarose TAE gel. Perform gel extraction using the QIAquick gel extraction kit according to the manufacturer's instructions. Use $10 \mu \mathrm{l}$ of a $100 \mathrm{ng} \mu \mathrm{l}^{-1} 1$-kb ladder to check the size of PCR products, which should be 1416 bp for iTol2-amp, $1368 \mathrm{bp}$ for iTol2-kan and 1,662 bp for iTol2-galK. Collect PCR product with sterile $\mathrm{H}_{2} \mathrm{O}$ into a sterile 1.5-ml tube at a final concentration of $0.2-1 \mu \mathrm{g} \mu \mathrm{l}^{-1}$. Typically, this PCR product is enough for recombineering 20-30 BACs.

PAUSE POINT PCR product can be stored at $-20^{\circ} \mathrm{C}$ for several weeks.

21| Pick two single SW102 colonies containing the BAC (from Step 15) into 14-ml round-bottom tubes containing $5 \mathrm{ml}$ of LB-chloramphenicol and shake overnight at $32{ }^{\circ} \mathrm{C}, 210$ r.p.m.

22| Transfer $500 \mu \mathrm{l}$ of overnight SW102:BAC culture into $25 \mathrm{ml}$ LB-chloramphenicol (prewarmed to RT) in a 50-ml flask. Grow cells at $32{ }^{\circ} \mathrm{C}, 210$ r.p.m., until $\mathrm{OD}_{600}$ reaches $0.55-0.6$. This takes approximately 3-4 h.

$\triangle$ CRITICAL STEP Do not harvest cells under or overgrown before proceeding to the next step. It is crucial that the $0 \mathrm{D}_{600}$ is within 0.55-0.6. If not, restart Step 22.

? TROUBLESHOOTING

23 Prepare ice/sterile water slush in a Styrofoam box, and place inside it for each flask: $50 \mathrm{ml}$ of autoclaved Milli- $Q$ water, 2 $15-\mathrm{ml}$ Falcon tubes, $21.5-\mathrm{ml}$ Eppendorf tubes. Place $610-\mathrm{ml}$ pipettes and 2 electroporation cuvettes in a refrigerator at $4^{\circ} \mathrm{C}$. 
24| Heat-shock the SW102 cells with BAC at $42{ }^{\circ} \mathrm{C}$ for exactly 15 min, shaking at 210 r.p.m. (or by hand every 4 min). $\triangle$ CRITICAL STEP The cells must not be heat shocked longer than $15 \mathrm{~min}$ and should be shaken periodically to ensure even heat transfer.

25 Place the cells in a flask (from Step 24) on ice/water slush immediately. Allow to cool for 5 min. Mix gently by inverting up/down and transfer $10 \mathrm{ml}$ from each to a $15-\mathrm{ml}$ Falcon tube. Store the rest at $4{ }^{\circ} \mathrm{C}$.

26| Centrifuge the tubes for $5 \mathrm{~min}$ at 4,500 $\mathrm{g}$ in an Eppendorf centrifuge precooled to $0^{\circ} \mathrm{C}$. Immediately after the spin is completed, transfer the tubes to ice/water slush.

27| Carefully but rapidly drain out the supernatant by inverting the tubes without disturbing the pellet. Resuspend pellet by adding $10 \mathrm{ml}$ of prechilled autoclaved Milli- $Q$ water using a chilled $10-\mathrm{ml}$ pipette.

$\Delta$ CRITICAL STEP Carefully resuspend by keeping tubes inside the ice/water slush at this and all steps, because warming or harsh treatment of cells will reduce the success of recombineering drastically.

28 Centrifuge for $5 \mathrm{~min}$ at 4,500g in an Eppendorf centrifuge precooled to $0^{\circ} \mathrm{C}$. Immediately after the spin is completed, transfer the tubes to ice/water slush. Repeat Steps 27 and 28.

29| Carefully but rapidly drain out the supernatant by inverting the tubes without disturbing the pellet. This time, ensure that virtually all supernatant is drained out, except for $\sim 50 \mu \mathrm{l}$ left at the bottom, by inverting the tube on tissue paper and tapping it a few times. Transfer this $50 \mu \mathrm{l}$ of competent cells to a new prechilled $1.5-\mathrm{ml}$ tube and keep it on ice until you are ready for electroporation.

$\triangle$ CRITICAL STEP The cells should be used immediately, but within 30 min at the latest.

30| Mix $50 \mu$ l of cells and 1-2 $\mu$ g of iTol2 cassette and electroporate as described in Steps 12 and 13.

31| Recover cells with $1 \mathrm{~mL}$ of LB and grow at $32{ }^{\circ} \mathrm{C}$ for $1 \mathrm{~h}$. Keep a $100-\mu \mathrm{l}$ aliquot of these cells for plating (Step 32). Centrifuge the remaining $900 \mu \mathrm{l}$, then remove all supernatant except the 'bottom' $100 \mu \mathrm{l}$ and resuspend the pellet by tapping a few times.

32 Plate $100 \mu \mathrm{l}$ of the cells before and after centrifugation on LB-chloramphenicol-ampicillin agar plates for iTol2-amp and on LB-chloramphenicol-kanamycin for iTol2-kan. To avoid false positives, make replica plates from the same colonies on both LB-chloramphenicol-kanamycin and LB-chloramphenicol-spectinomycin agar plates. For iTol2-galK, plate transformed cells on M63 minimal plates with chloramphenicol. Incubate overnight at $32{ }^{\circ} \mathrm{C}$ for iTol2-amp and iTol2-kan and 3 days for iTol2-galK. ? TROUBLESHOOTING

\section{Recombineering a reporter gene into the Tol2-BAC plasmid}

33| To introduce a reporter gene into the BAC, we recommend one of the following two options, depending on the aim of the experiment. Option A consists of recombineering a kanamycin cassette and overnight selection on LB-agar medium. This option is ideal for modifying many BACs in parallel. Option B involves recombineering a galK cassette, $3 \mathrm{~d}$ of positive selection on minimal medium, followed by a second round of recombineering with a reporter gene and $3 \mathrm{~d}$ of negative selection on DOG minimal medium. This option is best for making a translational fusion and for creating precise deletions or point mutations inside a BAC.

(A) Recombineering a reporter gene by kanamycin selection $\bigcirc$ TIMING $2 \mathbf{d}$

(i) Amplify the GFP-pA-FRT-kan-FRT, Gal4FF-pA-FRT-kan-FRT, Gal4VP16-pA-FRT-kan-FRT or Cre-pA-FRT-kan-FRT cassette (Fig. 2b and Supplementary Data) according to the conditions used in Steps 17 and 18, except that the extension time should be increased to 2 min $40 \mathrm{~s}$. Use $1 \mathrm{ng}$ of the plasmid DNA and gene-specific primers (geneX_GFP_fw, geneX_Gal4FF_fw, geneX_Gal4-VP16_fw or geneX_Cre_fw and geneX_frt-kan-rev) designed to match 50 bp upstream and downstream of the chosen target site on the BAC plasmid (see REAGENT SETUP and Table 4).

(ii) Remove the plasmid DNA template by digesting the PCR product with $2 \mu \mathrm{l}$ of DpnI. Incubate it at $37^{\circ} \mathrm{C}$ for $6-8 \mathrm{~h}$.

(iii) Precipitate $95 \mu \mathrm{l}$ of PCR product by adding $5 \mu \mathrm{l}$ of $5 \mathrm{M} \mathrm{LiCl}$ and $300 \mu \mathrm{l}$ of $99.7 \%$ (vol/vol) ethanol. Mix well and place for $30 \mathrm{~min}$ at $-20^{\circ} \mathrm{C}$. Run the remaining $5 \mu \mathrm{l}$ of PCR product on a $1 \%$ (wt/vol) TAE-agarose gel to check the success of PCR.

- PAUSE POINT PCR product can be stored at $-20^{\circ} \mathrm{C}$ overnight.

(iv) Centrifuge the precipitated PCR product at $19,300 \mathrm{~g}$ for $15 \mathrm{~min}$ at $4^{\circ} \mathrm{C}$.

(v) Carefully wash the pellet once with $1 \mathrm{ml}$ of $70 \%$ (vol/vol) ethanol.

(vi) Dry the pellet at $25^{\circ} \mathrm{C}$ for 5-10 min. 
(vii) Resuspend in $10 \mu \mathrm{l}$ of nuclease-free water.

(viii) Use $1 \mu \mathrm{l}$ of the suspension to measure DNA concentration with a spectrophotometer. Concentration is normally in the range approximately $2-5 \mu \mathrm{g} \mu \mathrm{l}^{-1}$.

(ix) Pick a colony using a plastic filtered tip on a P20 pipette from SW102 cells harboring Tol2-BAC (from Step 32) and transfer it into a 14-ml round-bottom tube containing $5 \mathrm{ml}$ of LB-chloramphenicol-ampicillin. Grow overnight at $32{ }^{\circ} \mathrm{C}$ with shaking at 210 r.p.m.

(x) Add $500 \mu \mathrm{l}$ of the overnight culture into $25 \mathrm{ml}$ of LB-chloramphenicol-ampicillin. Grow cells at $32{ }^{\circ} \mathrm{C}$ to $\mathrm{OD}_{600}=0.55-0.6(3-4 \mathrm{~h})$ with shaking at 210 r.p.m.

(xi) Prepare competent cells as described in Steps 23-29.

(xii) Transform the cells with kan cassette DNA (5-10 $\mu \mathrm{g}$ ) by electroporation as described in Steps 12 and 13.

(xiii) Recover cells and plate on LB-chloramphenicolampicillin-kanamycin agar plates according to Steps 14 and 15. To avoid false positives, make replica plate colonies on LB-chloramphenicol-ampicillin-spectinomycin agar plates.

(xiv) Pick 10-12 colonies from the LB-chloramphenicol-ampicillin-kanamycin agar plates (which did not grow on spectinomycin) and prepare plasmid DNA according to Box 2.

\section{? TROUBLESHOOTING}

(xv) Analyze DNA by restriction enzyme digestion with SalI or SpeI. Run it on a $0.8 \%$ (wt/vol) agarose gel and photograph the gel under UV illumination. Compare the digestion pattern of the original BAC, Tol2-BAC and final Tol2-BAC reporter plasmids (Fig. 5).

\section{? TROUBLESHOOTING}

(xvi) Confirm homologous recombination by PCR amplification using gene-specific primers (see REAGENT SETUP) and sequence the reporter gene using GFP_seqF, Gal4FF_seqF, Gal4-VP16_seqF or Cre_seqF and Kan_seqR primers, depending on the cassette (Table 4).

(B) Recombineering a reporter gene by galK selection $\bigcirc$ TIMING $6 \mathrm{~d}$

(i) Amplify the galK cassette (Fig. 2b) by PCR using $1 \mathrm{ng}$ of the pgalK plasmid and gene-specific primers (geneX_galK_fw and geneX_galK_rev) with homologies designed to match 50 bp upstream and downstream of the chosen target site on the BAC plasmid (see REAGENT SETUP and Table 4). Set up PCR reactions and conditions as described in Steps 17 and 18.

(ii) Digest the PCR product to remove the plasmid DNA template and purify as described in Steps 19 and 20.

$\square$ PAUSE POINT PCR product can be stored at $-20^{\circ} \mathrm{C}$ for several weeks.

(iii) Pick a colony using a plastic filtered tip on a P20 pipette from SW102 cells harboring Tol2-BAC (Step 32) and transfer it into a 14- $\mathrm{ml}$ round-bottom tube containing $5 \mathrm{~mL}$ of LB with chloramphenicol and ampicillin. Grow overnight at $32{ }^{\circ} \mathrm{C}$ with shaking at 210 r.p.m.

(iv) Add $500 \mu \mathrm{l}$ of the overnight culture into $25 \mathrm{ml}$ of LB with chloramphenicol and the iTol2 cassette antibiotic (ampicillin or kanamycin). Grow cells at $32{ }^{\circ} \mathrm{C}$ to $\mathrm{OD}_{600}=0.55-0.6(\sim 4 \mathrm{~h})$ with shaking at 210 r.p.m.

(v) Prepare competent cells as described in Steps 23-29.

(vi) Transform the cells with galK cassette DNA (25-50 ng) by electroporation as described in Steps 12 and 13.

(vii) Transfer the bacteria to a $14-\mathrm{ml}$ bacterial round-bottom tube with $1 \mathrm{~mL}$ of LB; incubate at $32{ }^{\circ} \mathrm{C}$ for $1 \mathrm{~h}$ with shaking at 210 r.p.m.

(viii) Wash the bacteria twice with 1× M9 medium. Resuspend the pellet in $1 \mathrm{~mL}$ of $1 \times$ M9 medium, and plate 10, 100 and $250 \mu \mathrm{l}$ of cells onto M63 minimal medium plates with chloramphenicol (and ampicillin or kanamycin). Incubate at $32{ }^{\circ} \mathrm{C}$ for $3 \mathrm{~d}$.

(ix) Pick colonies and streak on MacConkey agar plates with chloramphenicol. Pick single bright red $\left(\mathrm{Gal}^{+}\right)$colored colonies and grow them in $5 \mathrm{ml}$ of LB-chloramphenicol-ampicillin or LB-chloramphenicol-kanamycin at $32{ }^{\circ} \mathrm{C}$ overnight. ? TROUBLESHOOTING

(x) Amplify the reporter gene (e.g., GFP, Gal4FF, Gal4-VP16 or Cre) by PCR using the plasmids in Figure $\mathbf{2 b}$ as templates and gene-specific primers (e.g., geneX_GFP_fw and geneX_pA_rev in Table 4) containing the same 50-bp homologies used for the galK primers in Step 33B(i). Digest the PCR product with DpnI and purify by gel extraction as described in Steps 19 and 20. Alternatively, use double-stranded oligos containing a point mutation, deletion or insertion to create the appropriate modification at the target site $^{38}$. 
(xi) Introduce 1-2 $\mu \mathrm{g}$ of PCR product or double-stranded oligos into $\mathrm{Gal}^{+}$cells from Step 33B(ix) according to the electroporation procedure described in Steps 12 and 13.

(xii) Transfer the cells to $10 \mathrm{~mL}$ of LB and incubate at $32{ }^{\circ} \mathrm{C}$ for $4.5 \mathrm{~h}$ with shaking at 210 r.p.m.

(xiii) Wash the bacteria twice with $1 \times$ M9 medium. Resuspend the pellet in $1 \mathrm{ml}$ of $1 \times \mathrm{M} 9$ medium, and plate 10,100 and $250 \mu$ of cells onto DOG minimal medium plates with chloramphenicol and ampicillin or kanamycin. Incubate at $32{ }^{\circ} \mathrm{C}$ for $3-4 \mathrm{~d}$.

(xiv) Prepare plasmid DNA from 10 to 12 colonies according to Box 2 and analyze BAC DNA as described in Steps $33 \mathrm{~A}(\mathrm{xvi})$ and $33 \mathrm{~A}$ (xvii).

\section{? TROUBLESHOOTING}

\section{Microinjection of the Tol2-BAC DNA and TP RNA TIMING 3 d}

34| Prepare recombineered BAC DNA using the Nucleobond BAC 100 kit according to the manufacturer's instructions. Next, purify DNA by phenol-chloroform-isoamyl alcohol extraction, precipitate with one-tenth volume of $3 \mathrm{M}$ sodium acetate ( $\mathrm{pH} 5.2$ ) and 3 volumes of $99.7 \%$ ( $\mathrm{vol} / \mathrm{vol}$ ) ethanol, rinse once with $70 \%$ ( $\mathrm{vol} / \mathrm{vol}$ ) ethanol and resuspend in nuclease-free water at $250 \mathrm{ng}^{-1} \mathrm{l}^{-1}$. To resuspend the BAC DNA, flick the tube gently several times and let it rest at $25^{\circ} \mathrm{C}$ for at least $1 \mathrm{~h}$. Keep a small aliquot of the BAC DNA at $4^{\circ} \mathrm{C}$ for immediate use and store the rest at $-20^{\circ} \mathrm{C}$. Avoid repeated freeze/thawing of the BAC DNA before microinjection.

! CAUTION Phenol is toxic by inhalation, ingestion or contact with skin. Wear suitable gloves and work in a fume hood.

$\triangle$ CRITICAL STEP Never vortex or pipette BAC DNA up and down, as this will lead to shearing.

$\triangle$ CRITICAL STEP Avoid transferring any of the bottom phenol layer and any material at the interface during DNA extraction. Impurities and/or phenol are highly toxic to embryos and will likely result in mortality upon microinjection (Step 44).

35 Digest pCS2-zT2TP (Fig. 3a) with NotI and purify by phenol-chloroform-isoamyl extraction followed by chloroform extraction. Ethanol precipitate, rinse once with $70 \%$ ( $\mathrm{vol} / \mathrm{vol}$ ) ethanol and dissolve in nuclease-free water at the concentration of $\sim 1 \mu \mathrm{g} \mu \mathrm{l}^{-1}$.

36| Use mMESSAGE mMACHINE SP6 kit to synthesize Tol2 TP mRNA from $1 \mu \mathrm{g}$ of the linearized template according to the manufacturer's instruction.

37| Add nuclease-free water to the synthesized mRNA to a final volume of $100 \mu \mathrm{l}$ and purify the sample with a mini quickspin RNA column according to the manufacturer's instruction. Adjust the volume of the eluted solution to $135 \mu \mathrm{l}$. Add $15 \mu \mathrm{l}$ of ammonium acetate stop solution and extract the mRNA once with an equal volume of phenol-chloroform-isoamyl alcohol and then with an equal volume of chloroform. Transfer the aqueous phase to a new tube.

38| Add an equal volume of isopropanol, mix well, chill the mixture at least for $15 \mathrm{~min}$ at $-20{ }^{\circ} \mathrm{C}$ and centrifuge the mixture at $4^{\circ} \mathrm{C}$ for $15 \mathrm{~min}$ at maximum speed. Carefully remove the supernatant and resuspend the precipitated mRNA in $50 \mu \mathrm{l}$ of nuclease-free water. Approximately $30 \mu \mathrm{g}$ of mRNA will be synthesized. Take an aliquot and adjust the concentration to $250 \mathrm{ng} \mu \mathrm{l}^{-1}$ for microinjection. Store it in $5-\mu \mathrm{l}$ aliquots at $-80^{\circ} \mathrm{C}$.

! CAUTION Isopropanol is very flammable and irritating to eyes; inhalation may cause dizziness and nausea.

PAUSE POINT Transposase mRNA can be stored at $-80^{\circ} \mathrm{C}$ for several months.

39| Ensure that MPPI-3 microinjection system is working properly, including the air supply (Fig. 6), and prepare a dish for holding the embryos in place during microinjection (see EQUIPMENT SETUP and Fig. 6b). 
40| Place one or two male and one or two female zebrafish in separate compartments of a 3-liter mating box in the late afternoon after feeding (Fig. $\mathbf{6 d}$ ). Prepare enough mating boxes to set up four to six pair matings to obtain enough eggs for several rounds of injection in a given morning.

41| The next morning, prepare the BAC DNA/RNA injection mixture in a 0.5-ml RNAse-free tube as follows, mix by gently flicking the tube several times and always keep on ice:

\begin{tabular}{lcc}
\hline Component & Amount $(\mu \mathrm{l})$ & Final \\
\hline Tol2-BAC plasmid DNA $\left(250 \mathrm{ng} \mathrm{\mu l}^{-1}\right)$ & 4 & $1 \mu \mathrm{g}$ \\
Tol2 transposase RNA $\left(250 \mathrm{ng} \mathrm{\mu l}^{-1}\right)$ & 4 & $1 \mu \mathrm{g}$ \\
$\mathrm{KCl}(0.4 \mathrm{M})$ & 10 & $0.2 \mathrm{M}$ \\
Phenol red solution $(2.5 \%, \mathrm{wt} / \mathrm{vol})$ & 2 & $0.25 \%$ \\
\hline
\end{tabular}

$\triangle$ CRITICAL STEP Do not vortex or pipette BAC DNA mixture up and down, as this will lead to breakage of the Tol2-BAC plasmid.

42| Prepare fine needles for microinjection (Fig. 6c) by pulling a glass capillary, and break the tip with fine forceps. Load $3 \mu \mathrm{l}$ of the DNA/RNA mixture into the glass capillary needle using a P20 pipette and Microloader tips. Attach the capillary (Fig. 6c) to the needle holder of the MPPI-3 pressure injection system (Fig. 6a). Set the pressure to 20 psi and adjust the pulse duration to $50 \mathrm{~ms}$.

43| Mate fish in one 3-liter mating box (from Step 40) at a time by placing male and female fish together in the upper compartment and wait until they lay eggs. Collect eggs into Petri dishes with E3 medium. Microinjection should be carried out at the one-cell stage, namely within 20-30 min after fertilization.

44| Line up 60 newly fertilized zebrafish eggs (obtained from paired matings in Step 43) inside an embryo injection dish (Fig. 6b) containing E3 medium. Once each embryo is in place, rapidly penetrate the chorion of the one-cell-stage embryo with the tip of the needle (Fig. 6 c, asterisk), and then move slowly into the boundary between the yolk and cytoplasm. Once the needle is inside the cytoplasm, inject enough solution to fill at least one-tenth of the cytoplasmic volume. Repeat Step 43 and inject 100-200 embryos for each BAC construct. Save some uninjected embryos as controls to check the health of the clutch. Incubate the injected embryos in E3 medium at $28.5^{\circ} \mathrm{C}$ in Petri dishes until the desired age for use in the following steps.

$\triangle$ CRITICAL STEP It is crucial to inject the DNA/RNA mix directly into the cell (not into the yolk) at the one-cell stage. The phenol red included in the solution helps monitor the location and amount of solution injected. If necessary, an eyepiece graticule and micrometer slide can be used to measure the relative volume of the injected solution. A useful site describing the use of the graticule can be found at http://www.cavehill.uwi.edu/FPAS/bcs/courses/Biology/BIOL2053/ 2053proj/biol2053estimating\%20size.htm.

? TROUBLESHOOTING

\section{Confirmation of Tol2-mediated BAC excision in injected embryos $\bigcirc$ TIMING $2 \mathrm{~d}$}

45 Transfer eight injected embryos from Step 44 at $10 \mathrm{~h}$ post fertilization (hpf) to wells in an eight-strip PCR tube. Remove as much E3 medium as possible. Add $50 \mu \mathrm{l}$ of embryo lysis buffer. Incubate at $50{ }^{\circ} \mathrm{C}$ overnight. Inactivate the enzyme at $95^{\circ} \mathrm{C}$ for $10 \mathrm{~min}$.

$\triangle$ CRITICAL STEP It is crucial to inactivate the proteinase $\mathrm{K}$ at $95^{\circ} \mathrm{C}$ for $10 \mathrm{~min}$. Failure to do so will result in no PCR amplification in the following steps.

PAUSE POINT Embryo extracts can be stored at $-20^{\circ} \mathrm{C}$ for several weeks.

46 Combine the reagents tabulated below to make an $8 x$ master mix for the PCR 'excision assay'. Below we list the primers for the iTol2-amp cassette, but details of excision primers for the iTol2-kan and iTol2-galK cassettes are also provided in Table 4. Dispense $20 \mu \mathrm{l}$ of this mix per tube and add $1 \mu \mathrm{l}$ of the embryo extract from Step 45. 
PROTOCOL

\begin{tabular}{lcc}
\hline Component & Amount $(\mu \mathrm{l})$ & Final \\
\hline Buffer $(5 \times)$ with green loading dye & 32 & $1 \times$ \\
$\mathrm{MgCl}_{2}(25 \mathrm{mM})$ & 16 & $2.5 \mathrm{mM}$ \\
dNTP mixture $(10 \mathrm{mM})$ & 3.2 & $0.2 \mathrm{mM}$ \\
Primer iT2amp-exc168F $(50 \mu \mathrm{M})$ & 3.2 & $1 \mu \mathrm{M}$ \\
Primer iT2amp-exc168R $(50 \mu \mathrm{M})$ & 3.2 & $1 \mu \mathrm{M}$ \\
GoTaq Flexi DNA polymerase $\left(5 \mathrm{U} \mu \mathrm{L}^{-1}\right)$ & 1.6 & $8 \mathrm{U}$ \\
Nuclease-free water & To 160 & \\
\hline
\end{tabular}

47| Run the PCR with the following conditions:

\begin{tabular}{lccc}
\hline Cycle number & Denature & Anneal & Extend \\
\hline 1 & $94^{\circ} \mathrm{C}, 2 \mathrm{~min}$ & & \\
$2-35$ & $94^{\circ} \mathrm{C}, 30 \mathrm{~s}$ & $55^{\circ} \mathrm{C}, 30 \mathrm{~s}$ & $72{ }^{\circ} \mathrm{C}, 1 \mathrm{~min}$ \\
36 & & & $72^{\circ} \mathrm{C}, 5 \mathrm{~min}$ \\
\hline
\end{tabular}

48 Check $10 \mu \mathrm{l}$ of the PCR samples by agarose gel electrophoresis (2\% (wt/vol) agarose in TAE). The excision product (336 bp) should be detected from embryos injected with both the Tol2-BAC plasmid and the TP mRNA but not from embryos injected with Tol2-BAC plasmid only (Fig. 4b).

$\triangle$ CRITICAL STEP If no excision product is detected, the injected embryos should be discarded. Check the quality of BAC DNA and TP RNA and repeat injection (or restart from Step 34).

? TROUBLESHOOTING

\section{Selection and rearing of Tol2-BAC-injected fish $\bigcirc$ TIMING 3-4 months}

49| If injected embryos $\left(F_{0}\right)$ are expected to express fluorescent proteins such as GFP, screen the injected embryos/larvae for fluorescence under a dissection microscope equipped with UV light and appropriate filters. Record the tissues and cells that show fluorescence. Separate embryos/larvae with very bright and/or even fluorescence signals and grow them separately from the rest. Stronger fluorescence can be correlated with higher integration rates (M.L.S., unpublished observations). Transfer up to 30 injected larvae at 5 days post fertilization (dpf) from Step 44 into a 200-ml Pyrex glass beaker. Grow larvae in beakers until $12 \mathrm{dpf}$, and then transfer them to 2-liter tanks until they are 2 months old (Fig. $6 \mathrm{~d}$ ). Finally, raise them until they are sexually mature (3-4 months) in 12-liter tanks (Fig. 6e).

\section{? TROUBLESHOOTING}

\section{Screening of Tol2-BAC-injected fish $\bigcirc$ TIMING $3 \mathrm{~d}$}

50| Identify $\mathrm{F}_{0}$ fish with integrations in the germline, by mating single fish as described below and screening their progeny either by visualization of the fluorescence signal (option A) or by PCR screening (option B).

\section{(A) Fluorescence screening}

(i) Place single male or female injected fish in mating boxes in the late afternoon, at least $1 \mathrm{~h}$ after feeding. If the BAC carries the GFP reporter, mate the injected fish with wild-type fish. If the BAC carries Gal4, mate the injected fish with UASGFP fish ${ }^{10}$.

(ii) Collect eggs the next morning in E3 medium and examine them every day from $10 \mathrm{hpf}$ to $5 \mathrm{dpf}$ for fluorescence (Fig. 7). ? TROUBLESHOOTING

(iii) Set aside founder fish whose progeny show stable expression of the reporter gene in the correct pattern ${ }^{33,37}$ (e.g., Fig. 7a,d,e; see Supplementary Fig. 1 for comparison of reporter gene and endogenous expression). ? TROUBLESHOOTING

(iv) Raise the fluorescence-positive F1 progeny to adulthood and maintain stable lines by outcrossing. $\triangle$ CRITICAL STEP A minimum of 50 (and ideally 100) embryos should be observed from each mating. On average, there is a strong correlation between transmission frequency in the F1 progeny and transgene copy number. As Tol2 tends to generate single-copy BAC integrations, very few embryos are expected to show fluorescence in a clutch. 
Figure 7 | Generation and identification of Tol2$B A C$ transgenic fish. (a) Schematic of the $\sim 70-k b$ Tol2BAC-Fugu evx1:Gal4FF plasmid containing the exon 2:Gal4FF fusion downstream of the hoxA cluster. Gray box is the plasmid backbone. $(b, c)$ Transient mosaic expression Fugu evx1: Gal4FF after co-injection with TP RNA into homozygous UAS:GFP fertilized eggs at $10 \mathrm{~h}$ post fertilization (hpf) (b) and 4 days post fertilization (dpf) (c). GFP expression is observed widely at $10 \mathrm{hpf}$, but becomes very restricted to commissural neurons by $4 \mathrm{dpf}$ (arrowheads). Transient 'ectopic' expression is observed in muscle cells. (d,e) Double-transgenic Tol2BACFugu evx1:Gal4FF; UAS:GFP larvae obtained by mating two founder fish (nos. 18 (d) and 43 (e)) and homozygous UAS:GFP. A total of $5 \%$ (2 of 40) founder fish were germline carriers. GFP expression is localized to neurons in the hindbrain ( $\mathrm{hb}$ ) and spinal cord (sc). The arrowhead shows GFP expression in cloaca consistent with endogenous evx1 expression. $(\mathbf{f}, \mathbf{g})$ Tol2BAC-fgf24:GFP-1 ( 165 kb) (f) and Tol2BAC-fgf24:GFP-2 ( 140 kb) (g) contain a fusion of GFP and exon 1 of $f g f 24$. (h,i) Transient mosaic GFP expression at $10 \mathrm{hpf}(\mathbf{h})$ and $30 \mathrm{hpf}(\mathbf{i})$.

Arrowheads point to the otic vesicle. (j) Representative embryo from stable transgenic Tol2BAC-fgf24:GFP-2 at 24 hpf. Arrowheads point to the main sites of GFP expression that recapitulate endogenous fgf24 expression (see Supplementary Fig. 1). A total of $20 \%$ (5 of 25) and $22 \%$ (2 of 9 ) of fish injected with Tol2BAC-fgf24:GFP-1 and Tol2BAC-fgf24:GFP-2 were germline carriers. Scale bars, $\mathbf{b}, \sim 1980 \mu \mathrm{m} ; \mathbf{c}, \mathbf{e}, \sim 250 \mu \mathrm{m} ; \mathbf{h}, \sim 1875 \mu \mathrm{m} ; \mathbf{i}, \sim 278 \mu \mathrm{m} ;$ and $\mathbf{j}, \sim 400 \mu \mathrm{m}$.

\section{(B) PCR screening}

(i) Place a single male or female injected fish in mating boxes in the late afternoon, at least $1 \mathrm{~h}$ after feeding.

(ii) Collect 20-50 embryos in $200 \mu \mathrm{l}$ of embryo lysis buffer and follow Steps 46-47 with primers specific for each reporter gene (e.g., GFP_seqF, Gal4FF_seqF, Gal4-VP16_seqF or Cre_seqF and pA_seqR in Table 4).

(iii) Run a $1-2 \%$ (wt/vol) agarose gel and visualize PCR products under UV light. ? TROUBLESHOOTING

(iv) Set aside injected fish whose embryo clutches were PCR positive. Mate these fishes again as described in Step 50B(i) and grow their progeny until adulthood.

\section{Analysis of Tol2-BAC integrations (optional) TIMING $3 \mathrm{~d}$}

51| Extract genomic DNA from transgenic adult zebrafish tail fins according to Box 3; include extracts from an adult wildtype control and an adult UASGFP control fish. Southern blot hybridization can be used to determine the actual number of transposon insertions as described previously ${ }^{33,53}$. However, as Tol2 typically generates one or two BAC integrations in the zebrafish germline, it is relatively easy to retrieve the Tol2-genomic junctions by inverse PCR or ADL-PCR. Steps 52-60 describe how to retrieve the genomic junctions by ADL-PCR and determine the BAC integration site. The full procedure is illustrated in Figure $\mathbf{8}$ along with typical results.

\section{Box 3 | Preparation of genomic DNA from zebrafish tail fin $\bigcirc$ TIMING 1 d}

1. Anesthetize adult fish with tricaine.

2. Cut one-third of the tail fin with a blade and submerge in $200 \mu \mathrm{l}$ of DNA extraction buffer in a 1.5-mL Eppendorf tube. Return the fish immediately to system water.

3. Incubate at $50{ }^{\circ} \mathrm{C}$ overnight, and dissolve the tail fin completely.

4. Purify DNA by phenol-chloroform extraction.

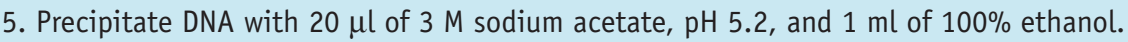

6. Rinse once with $70 \%$ ( $\mathrm{vol} / \mathrm{vol}$ ) ethanol and resuspend in $50 \mu \mathrm{l}$ of TE.

7. Measure DNA concentrations by using a spectrophotometer. 
Figure $\mathbf{8}$ | Analysis of Tol2-BAC integrations. (a) A section of the tail fin from adult Tol2BAC-Fugu evx1:Gal4FF fish was cut for DNA extraction.

(b) Genomic DNA is digested with GATC or CTAG restriction enzymes (e.g., MboI) to create Tol2 genomic left (L) and right (R) fragments. After ligation of GATC or CTAG oligo 'adapters', the Tol2 genomic junctions are amplified in two steps (first and second PCR) with nested primers Ap1 and Ap2. The final products can be sequenced directly with Tol2-specific primers. (c,d) Schematic of the genomic integration sites of Tol2BAC-Fugu evx1:Gal4FF in two independent lines ${ }^{33}$. The duplicated sequence of the 8-bp target site is indicated. chr, chromosome; ntt4, orphan sodium- and chloride-dependent neurotransmitter transporter (solute carrier family 6 member 17); cng3, cyclic nucleotide gated channel beta 3 .

52 Set up a digest as tabulated below, and then incubate at $37^{\circ} \mathrm{C}$ for $1 \mathrm{~h}$ :

\begin{tabular}{lcc}
\hline Component & Amount $(\mu \mathrm{l})$ & Final \\
\hline Genomic DNA from Step 51 & Variable & $1 \mu \mathrm{g}$ \\
NE $(10 \times)$ buffer 4 & 2 & $1 \times$ \\
MboI $\left(5 \cup \mu \mathrm{l}^{-1}\right)$ & 1 & $10 \mathrm{U}$ \\
Nuclease-free water & To 20 & \\
\hline
\end{tabular}

53 Inactivate the enzyme at $70^{\circ} \mathrm{C}$ for $15 \mathrm{~min}$, set up a ligation reaction as tabulated below and incubate it at $16^{\circ} \mathrm{C}$ overnight. The next day, inactivate the ligase at $70{ }^{\circ} \mathrm{C}$ for $15 \mathrm{~min}$.

\begin{tabular}{lcc}
\hline Component & Amount $(\boldsymbol{\mu l})$ & Final \\
\hline MboI-digested DNA from Step 52 & 2 & Unknown \\
GATC adapter (see REAGENT SETUP) & 2 & Unknown \\
Takara (10x) ligase buffer & 2 & $1 \times$ \\
T4 DNA ligase (350 U $\left.\mu \mathrm{L}^{-1}\right)$ & 1 & $350 \mathrm{U}$ \\
Nuclease-free water & To 20 & \\
\hline
\end{tabular}

a

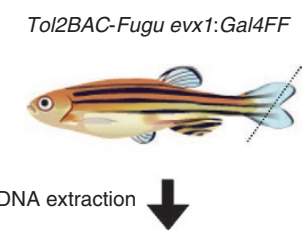

b
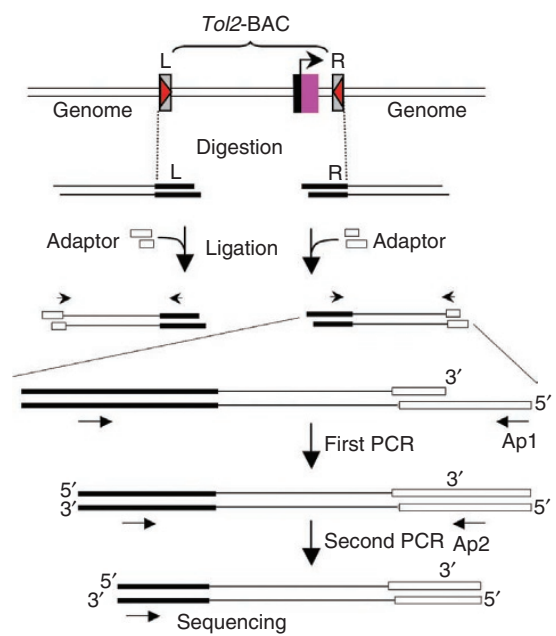

C Tol2-BAC18

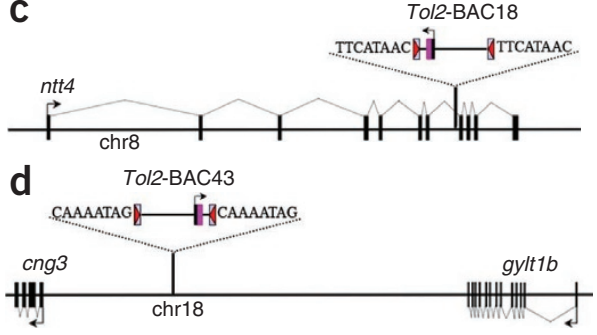

PAUSE POINT Inactivated ligation reactions can be stored at $-20^{\circ} \mathrm{C}$ overnight.

54| Dilute the entire ligation reaction tenfold by adding $180 \mu \mathrm{L}$ of $\mathrm{H}_{2} \mathrm{O}$. Set up the first PCR as tabulated below:

\begin{tabular}{lcc}
\hline Component & Amount $(\mu \mathrm{l})$ & Final \\
\hline Tenfold-diluted DNA from Step 53 & 2 & Unknown \\
Expand high-fidelity buffer $(10 \mathrm{x})$ with $\mathrm{MgCl}_{2}$ & 5 & $1 \times$ \\
dNTP $(10 \mathrm{mM})$ mixture & 1.5 & $0.3 \mathrm{mM}$ \\
Primer Ap1 $(50 \mu \mathrm{M})$ & 1 & $1 \mu \mathrm{M}$ \\
Primer 175L-out or 150R-out $(50 \mu \mathrm{M})$ & 1 & $1 \mu \mathrm{M}$ \\
Expand high-hidelity enzyme $\left(3.5 \mathrm{U} \mathrm{Ll}^{-1}\right)$ & 1 & $3.5 \mathrm{U}$ \\
Nuclease-free water & To 50 & \\
\hline
\end{tabular}


55| Run the PCR as follows:

\begin{tabular}{llll}
\hline Cycle number & Denature & Anneal & Extend \\
\hline 1 & $94^{\circ} \mathrm{C}, 30 \mathrm{~s}$ & & \\
$2-30$ & $94^{\circ} \mathrm{C}, 30 \mathrm{~s}$ & $57^{\circ} \mathrm{C}, 30 \mathrm{~s}$ & $72{ }^{\circ} \mathrm{C}, 1 \mathrm{~min}$ \\
31 & & & $72^{\circ} \mathrm{C}, 5$ min \\
\hline
\end{tabular}

56| Dilute tenfold by mixing $1 \mu \mathrm{l}$ of the PCR reaction from Step 55 and $9 \mu \mathrm{L}$ of $\mathrm{H}_{2} 0$. Set up the second PCR reaction as tabulated below:

\begin{tabular}{lcc}
\hline Component & Amount $(\mu \mathrm{l})$ & Final \\
\hline Tenfold-diluted DNA from Step 55 & 2 & Unknown \\
Expand high-fidelity buffer $(10 \times)$ with $\mathrm{MgCl}_{2}$ & 5 & $1 \times$ \\
dNTP $(10 \mathrm{mM})$ mixture & 1.5 & $0.3 \mathrm{mM}$ \\
Primer Ap2 $(50 \mu \mathrm{M})$ & 1 & $1 \mu \mathrm{M}$ \\
Primer $150 \mathrm{~L}-$ out or $100 \mathrm{R}-$ out $(50 \mu \mathrm{M})$ & 1 & $1 \mu \mathrm{M}$ \\
Expand high-fidelity enzyme $\left(3.5 \mathrm{U} \mu \mathrm{L}^{-1}\right)$ & 1 & $3.5 \mathrm{U}$ \\
Nuclease-free water & To 50 & \\
\hline
\end{tabular}

57| Run the PCR reaction with the same conditions described in Step 55.

58| Analyze $10 \mu \mathrm{l}$ of the sample on a 1.5\% (wt/vol) agarose/TAE gel electrophoresis. Purify the DNA bands that are observed in the BAC transgenic fish but not in wild-type control or UASGFP fish from the gel with the QIAquick gel extraction kit according to the manufacturer's instructions. Final volume will be $\sim 40 \mu \mathrm{l}$.

? TROUBLESHOOTING

59| Use $4 \mu \mathrm{l}$ of the DNA sample for sequencing with 100L-out, 100R-out and the BigDye terminator cycle sequencing kit according to the manufacturer's instructions. Mix the sample with a one-tenth volume of $3 \mathrm{M}$ sodium acetate and three volumes of $99.6 \%$ (vol/vol) ethanol. Incubate the sample at $25^{\circ} \mathrm{C}$ for $5 \mathrm{~min}$, centrifuge at $19,300 \mathrm{~g}$ for $20 \mathrm{~min}$ at $4{ }^{\circ} \mathrm{C}$, rinse with $70 \%$ (vol/vol) ethanol, dry and suspend in $20 \mu \mathrm{l}$ of HiDi formamide. Analyze the sample by sequencing (e.g., ABI PRISM 3130xl, Applied Biosystems).

60| BLAST the retrieved DNA sequences against the zebrafish genome using Ensembl and NCBI to find the precise location of the Tol2-BAC integration in the genome (Fig. 8c,d).

? TROUBLESHOOTING

\section{? TROUBLESHOOTING}

Troubleshooting advice can be found in Table 5. Specific troubleshooting tips for recombineering are available at http://recombineering.ncifcrf.gov/faq.asp.

TABLE 5 | Troubleshooting table.

\begin{tabular}{llll}
\hline Step & Problem & Possible reasons(s) & Solution(s) \\
\hline 13 & $\begin{array}{l}\text { Cells 'zapped' during } \\
\text { electroporation }\end{array}$ & Sample is too conductive & $\begin{array}{l}\text { Wash cells again to remove salts; discard sample and wash } \\
\text { remaining cells }\end{array}$ \\
\hline
\end{tabular}


PROTOCOL

TABLE 5 | Troubleshooting table (continued).

\begin{tabular}{|c|c|c|c|}
\hline Step & Problem & Possible reasons(s) & Solution(s) \\
\hline 22 & Poor culture growth & Bacteria are too old & Start culture from a fresh plate or restreak from glycerol stock \\
\hline \multirow{2}{*}{32} & & Electroporation failed & $\begin{array}{l}\text { Make sure PCR product is fresh and correct; pay careful } \\
\text { attention to preparation of electrocompetent cells and } \\
\text { growth medium; wash salts thoroughly }\end{array}$ \\
\hline & $\begin{array}{l}\text { Colonies grow on spec- } \\
\text { tinomycin replica plates }\end{array}$ & $\begin{array}{l}\text { Contamination with } p C R 8 G W \text {-iTol2 } \\
\text { plasmid }\end{array}$ & Ensure complete DpnI digestion (Step 19) \\
\hline \multirow[t]{2}{*}{$33 \mathrm{~A}(\mathrm{xiv})$} & No colonies on the plate & $\begin{array}{l}\text { Too little PCR product; } \\
\text { electroporation failed }\end{array}$ & See solutions for Step 32 \\
\hline & $\begin{array}{l}\text { Too many colonies on } \\
\text { the plate }\end{array}$ & $\begin{array}{l}\text { FRT-kan-FRT plasmid } \\
\text { contamination }\end{array}$ & Ensure complete DpnI digestion (Step 33A(ii)) \\
\hline $33 \mathrm{~A}(\mathrm{xv})$ & $\begin{array}{l}\text { The BAC DNA restriction } \\
\text { pattern looks strange }\end{array}$ & $\begin{array}{l}\text { Contamination with bacterial } \\
\text { genomic DNA; BAC DNA is damaged }\end{array}$ & $\begin{array}{l}\text { Repeat BAC DNA miniprep; use correct volumes of DNA } \\
\text { extraction solutions }\end{array}$ \\
\hline \multirow[t]{2}{*}{ 33B(ix) } & $\begin{array}{l}\text { No colonies on the M63 } \\
\text { minimal plate }\end{array}$ & $\begin{array}{l}\text { See possible reasons for } \\
\text { Step } 33 A(x v)\end{array}$ & See possible solutions for Step 33A(xv) \\
\hline & $\begin{array}{l}\text { Too many colonies on } \\
\text { the M63 minimal plates }\end{array}$ & pGalK plasmid contamination & Ensure complete DpnI digestion (Step 33B(ii)) \\
\hline \multirow[t]{2}{*}{44} & $\begin{array}{l}\text { Solution does not come } \\
\text { out of needle }\end{array}$ & Tip is too small or is clogged & Under a microscope, break the tip further with forceps \\
\hline & & Insufficient pressure & Increase the pressure in the MPPI injection system \\
\hline \multirow[t]{4}{*}{48} & $\begin{array}{l}\text { No excision product on } \\
\text { agarose gel }\end{array}$ & $\begin{array}{l}\text { TP RNA is degraded; PCR did } \\
\text { not work }\end{array}$ & $\begin{array}{l}\text { Check RNA by measuring } O D \text { and running on denaturing gel; } \\
\text { ensure that proteinase } \mathrm{K} \text { is inactivated (Step 45) }\end{array}$ \\
\hline & $\begin{array}{l}\text { Multiple bands or smear } \\
\text { on agarose gel }\end{array}$ & Too much genomic DNA & Use less embryo extract or dilute for PCR \\
\hline & & Primers are degraded & Store primers in Tris buffer at $-20{ }^{\circ} \mathrm{C}$ \\
\hline & & Annealing temperature too low & Increase annealing temperature by $1-2^{\circ} \mathrm{C}$ \\
\hline \multirow[t]{3}{*}{49} & High embryo mortality & DNA/RNA mixture is impure & Clean up DNA by phenol-chloroform extraction (Step 34) \\
\hline & & Too much DNA/RNA is injected & Reduce the amount of BAC DNA used in Step 41 \\
\hline & Larvae are dead 3-14 dpf & Transgene/reporter is toxic & $\begin{array}{l}\text { Reduce the amount of BAC DNA. If necessary, try a different } \\
\text { reporter (Gal4FF rather than Gal4-VP16) }\end{array}$ \\
\hline
\end{tabular}


TABLE 5 | Troubleshooting table (continued).

\begin{tabular}{|c|c|c|c|}
\hline Step & Problem & Possible reasons(s) & Possible solution(s) \\
\hline \multirow[t]{2}{*}{$\begin{array}{l}50 \mathrm{~A}(\mathrm{ii}) \\
50 \mathrm{~B}(\mathrm{iii})\end{array}$} & $\begin{array}{l}\text { No BAC transgene } \\
\text { positives }\end{array}$ & $\begin{array}{l}\text { Low or no germline transmission; } \\
\text { BAC transgene broke up }\end{array}$ & $\begin{array}{l}\text { Screen more founder fish } \\
\text { Use fresh transposase RNA } \\
\text { Prepare new BAC DNA and be careful to avoid shearing }\end{array}$ \\
\hline & $\begin{array}{l}\text { GFP pattern from BAC } \\
\text { transgenic fish does not } \\
\text { match endogenous gene } \\
\text { expression }\end{array}$ & $\begin{array}{l}\text { Reporter is silenced in germline; } \\
\text { BAC transgene is missing essen- } \\
\text { tial regulatory elements; } \\
\text { BAC transgene broke up }\end{array}$ & $\begin{array}{l}\text { Try a different BAC covering the gene of interest; screen } \\
\text { more founder fish; use larger BACs with surrounding genomic } \\
\text { sequence; prepare new BAC DNA. Avoid shearing }\end{array}$ \\
\hline \multirow[t]{2}{*}{58} & No PCR bands & $\begin{array}{l}\text { Poor quality of DNA extract; } \\
\text { ligation did not work (Step 53) }\end{array}$ & $\begin{array}{l}\text { Use embryos/larvae to prepare genomic DNA; ensure that } \\
\text { proteinase } \mathrm{K} \text { is inactivated (Step 51); check the ligase and } \\
\text { all reagents }\end{array}$ \\
\hline & Too many PCR bands & Problem with adapters or primers & $\begin{array}{l}\text { Ensure that adapters are working properly. Use a positive } \\
\text { control sample (e.g., UASGFP) and primers }\end{array}$ \\
\hline \multirow[t]{2}{*}{60} & $\begin{array}{l}\text { Sequence from ADL- } \\
\text { PCR products does not } \\
\text { match zebrafish genomic } \\
\text { sequence }\end{array}$ & $\begin{array}{l}\text { Template contamination; presence } \\
\text { of repeats in sequence } \\
\text { PCR artifact }\end{array}$ & $\begin{array}{l}\text { Ensure sterile handling of samples before PCR; try different } \\
\text { enzymes for digestion: BglII, BamHI, BclI for GATC adapter, } \\
\text { SpeI, XbaI, NheI, and AvrI for CTAG adapter } \\
\text { Try new template or high-quality genomic DNA }\end{array}$ \\
\hline & & Sequence is missing in browser & BLAST sequence against NCBI database \\
\hline
\end{tabular}

\section{TIMING}

Steps 1-5, Identification of BAC clones: $1 \mathrm{~d}$

Steps 6-15, Preparation of BAC-containing competent cells: $4 \mathrm{~d}$

Steps 16-32, Recombineering the iTol2 cassette into the BAC: $2 \mathrm{~d}$

Step 33, Recombineering a reporter gene into the Tol2-BAC plasmid: 2-6 d

Steps 34-44, Microinjection of the Tol2-BAC DNA and TP RNA: $3 \mathrm{~d}$

Steps 45-48, Confirmation of Tol2-mediated BAC excision in injected embryos: $2 \mathrm{~d}$

Step 49, Selection and rearing of Tol2-BAC injected fish: 3-4 months

Step 50, Screening of Tol2-BAC injected fish: $3 \mathrm{~d}$

Steps 51-60, Analysis of Tol2-BAC integrations (optional): $3 \mathrm{~d}$

Box 1, Preparation of SW102 electrocompetent cells: $1 \mathrm{~d}$

Box 2, BAC DNA miniprep: $2 \mathrm{~h}$

Box 3, Preparation of genomic DNA from zebrafish tail fin: $1 \mathrm{~d}$

\section{ANTICIPATED RESULTS}

Identification of BACs and construction of Tol2-compatible BAC transgenes by recombineering is relatively straightforward (Steps 1-33). It is easy to confirm the success of BAC modifications at every step of the procedure (Fig. 5). To confirm that the Tol2-BAC plasmid is intact and that the Tol2 mRNA works properly during microinjection, we highly recommend carrying out a PCR excision assay (Fig. 4b). After microinjection of 100 or so embryos per construct (Step 44), one can expect that approximately 5-20 of the injected fish will carry a stable germline integration of the Tol2-BAC construct. Germline transmission occurs in $\sim 15 \%$ of injected fish regardless of the source or size of the BAC DNA (70-165 kb and two different libraries, Fig. 7 and Supplementary Fig. 1). Although it is possible that there is a size limit for Tol2 inserts, we have not observed this yet. In the exceptional case where a BAC does not integrate stably in the germline, we assume that sequences in the BAC DNA itself could be unstable or have deleterious effects. Stable BAC transgenic fish are easily identified by detection of a fluorescent reporter inside the BAC (Fig. 7) or by PCR. We can anticipate that the integration site of the BAC construct in the genome can be easily deduced by PCR methods (Fig. 8c,d). Finally, our iTol2 cassettes and protocols for BAC transgenesis are readily applicable to a variety of model organisms, including mice ${ }^{33}$. 
Note: Supplementary information is available via the HTML version of this article.

ACKNOWLEDGMENTS For excellent fish care, we thank T. Kronstad, F. Silva and J. Xu at the Sars International Centre, and A. Ito, M. Suzuki, M. Mizushina, N. Mouri and T. Uematsu at the National Institute of Genetics. We thank A. Urasaki for initial characterization of zT2TP and K. Sumiyama for the $p B S K-G F P-p A-F R T-k a n-$ $F R T$ plasmid. This work was supported by core funding from the Sars International Centre, a fellowship from the Japan Society for the Promotion of Science and the Takeda Science Foundation to M.L.S., and grants from the National BioResource Project of Japan and the Ministry of Education, Culture, Sports, Science and Technnology of Japan to K.K.

AUTHOR CONTRIBUTIONS M.L.S. wrote the manuscript, directed the work at the Sars Centre and generated data and reagents. A.S. contributed reagents and optimized extensively the protocol. G.A. contributed data. K.K directed the work and wrote the manuscript.

COMPETING FINANCIAL INTERESTS The authors declare no competing financial interests.

Published online at http://www.natureprotocols.com/.

Reprints and permissions information is available online at http://www.nature. com/reprints/index.html.

1. Giraldo, P. \& Montoliu, L. Size matters: use of YACs, BACs and PACs in transgenic animals. Transgenic. Res. 10, 83-103 (2001).

2. Nagy, A., Gertsenstein, M., Vintersten, K. \& Behringer, R. Manipulating the Mouse Embryo: A Laboratory Manual, 3rd edn. (Cold Spring Harbor Press, Cold Spring Harbor, New York, USA, 2001).

3. Vintersten, K., Testa, G., Naumann, R., Anastassiadis, K. \& Stewart, A.F. Bacterial artificial chromosome transgenesis through pronuclear injection of fertilized mouse oocytes. Methods Mol. Biol. 415, 83-100 (2008).

4. Copeland, N.G., Jenkins, N.A. \& Court, D.L. Recombineering: a powerful new tool for mouse functional genomics. Nat. Rev. Genet. 2, 769-779 (2001).

5. Heintz, N. BAC to the future: the use of bac transgenic mice for neuroscience research. Nat. Rev. Neurosci. 2, 861-870 (2001).

6. Jessen, J.R., Willett, C.E. \& Lin, S. Artificial chromosome transgenesis reveals long-distance negative regulation of rag1 in zebrafish. Nat. Genet. 23, 15-16 (1999).

7. Yang, Z. et al. Modified bacterial artificial chromosomes for zebrafish transgenesis. Methods 39, 183-188 (2006).

8. Higashijima, S.-I. Transgenic zebrafish expressing fluorescent proteins in central nervous system neurons. Dev. Growth Diff. 50, 407-413 (2008).

9. Lieschke, G.J. \& Currie, P.D. Animal models of human disease: zebrafish swim into view. Nat. Rev. Genet. 8, 353-367 (2007).

10. Asakawa, K. et al. Genetic dissection of neural circuits by Tol2 transposon-mediated Gal4 gene and enhancer trapping in zebrafish. Proc. Natl. Acad. Sci. USA 105, 1255-1260 (2008).

11. Scott, E. et al. Targeting neural circuitry in zebrafish using Gal4 enhancer trapping. Nat. Methods 4, 323-326 (2007).

12. Emelyanov, A. \& Parinov, S. Mifepristone-inducible LexPR system to drive and control gene expression in transgenic zebrafish. Dev. Biol. 320, 113-121 (2008).

13. Langenau, D.M. et al. Cre/lox-regulated zebrafish model with conditional myc-induced T-cell acute lymphoblastic leukemia. Proc. Natl. Acad. Sci. USA 102, 6068-6073 (2005).

14. Knopf, F. et al. Dually inducible Tet0N systems for tissue-specific conditional gene expression in zebrafish. Proc. Natl. Acad. Sci. USA 107 19933-19938 (2010).

15. Chandler, K.J. et al. Relevance of BAC transgene copy number in mice: transgene copy number variation across multiple transgenic lines and correlations with transgene integrity and expression. Mamm. Genome 18 693-708 (2007).

16. Garrick, D., Fiering, S., Martin, D.I. \& Whitelaw, E. Repeat-induced gene silencing in mammals. Nat. Genet. 18, 56-59 (1998).

17. Dorer, D.R. Do transgene arrays form heterochromatin in vertebrates? Transgenic. Res. 6, 3-10 (1997).

18. Stuart, G.W., McMurray, J.V. \& Westerfield, M. Replication, integration and stable germ-line transmission of foreign sequences injected into early zebrafish embryos. Development 103, 403-412 (1988).

19. Amsterdam, A., Lin, S. \& Hopkins, N. The Aequorea victoria green fluorescent protein can be used as a reporter in live zebrafish embryos. Dev. Biol. 171, 123-129 (1995).

20. Long, Q. et al. GATA-1 expression pattern can be recapitulated in living transgenic zebrafish using GFP reporter gene. Development 124, 4105-4111 (1997).
21. Higashijima, S., Okamoto, H., Ueno, N., Hotta, Y. \& Eguchi, G. Highfrequency generation of transgenic zebrafish which reliably express GFP in whole muscles or the whole body by using promoters of zebrafish origin. Dev. Biol. 192, 289-299 (1997).

22. Rembold, M., Lahiri, K., Foulkes, N.S. \& Wittbrodt, J. Transgenesis in fish: efficient selection of transgenic fish by co-injection with a fluorescent reporter construct. Nat. Protoc. 1, 1133-1139 (2006).

23. Lin, S. et al. Integration and germ-line transmission of a pseudotyped retroviral vector in zebrafish. Science 265, 666-669 (1994).

24. Gaiano, N., Allende, M., Amsterdam, A., Kawakami, K. \& Hopkins, N. Highly efficient germ-line transmission of proviral insertions in zebrafish. Proc. Natl. Acad. Sci. USA 93, 7777-7782 (1996).

25. Ellingsen, $S$. et al. Large-scale enhancer detection in the zebrafish genome. Development 132, 3799-811 (2005).

26. Wang, D. et al. Efficient genome-wide mutagenesis of zebrafish genes by retroviral insertions. Proc. Natl. Acad. Sci. USA 104, 12428-12433 (2007).

27. Thomas, C.E., Ehrhardt, A. \& Kay, M.A. Progress and problems with the use of viral vectors for gene therapy. Nat. Rev. Genet. 4, 346-358 (2003).

28. Fadool, J.M., Hartl, D.L. \& Dowling, J.E. Transposition of the mariner element from Drosophila mauritiana in zebrafish. Proc. Natl. Acad. Sci. USA 95, 5182-516 (1998).

29. Kawakami, K. et al. A transposon-mediated gene trap approach identifies developmentally regulated genes in zebrafish. Dev. Cell 7, 133-144 (2004).

30. Davidson, A.E. et al. Efficient gene delivery and gene expression in zebrafish using the Sleeping Beauty transposon. Dev. Biol. 263, 191-202 (2003).

31. Kawakami, K. Tol2: a versatile gene transfer vector in vertebrates. Genome Biol. 8 (Suppl 1): S7 (2007).

32. Korzh, V. Transposons as tools for enhancer trap screens in vertebrates. Genome Biol. 8 (Suppl 1): S8 (2007).

33. Suster, M.L., Sumiyama, K. \& Kawakami, K. Transposon-mediated $B A C$ transgenesis in zebrafish and mice. BMC Genomics 10, 477 (2009).

34. Kawakami, K. \& Shima, A. Identification of the Tol2 transposase of the medaka fish Oryzias latipes that catalyzes excision of a nonautonomous Tol2 element in zebrafish Danio rerio. Gene 240, 239-244 (1999).

35. Balciunas, D. et al. Harnessing a high cargo-capacity transposon for genetic applications in vertebrates. PLoS Genet. 2, e169 (2006).

36. Urasaki, A., Morvan, G. \& Kawakami, K. Functional dissection of the Tol2 transposable element identified the minimal cis-sequence and a highly repetitive sequence in the subterminal region essential for transposition. Genetics 174, 639-649 (2006).

37. Suster, M.L. et al. A novel conserved evx1 enhancer links spinal interneuron morphology and cis-regulation from fish to mammals. Dev. Biol. 325, 422-433 (2009).

38. Sharan, K., Thomason, L.C., Kuznetsov, S.G. \& Court, D.L. Recombineering: a homologous recombination-based method of genetic engineering. Nat. Protoc. 4, 206-223 (2009).

39. Zhang, Z.D. et al. Statistical analysis of the genomic distribution and correlation of regulatory elements in the ENCODE regions. Genome Res. 17, 787-797 (2007).

40. Murphy, K.C. Use of bacteriophage I recombination functions to promote gene replacement in Escherichia coli. J. Bacteriol. 180, 2063-2071 (1998).

41. Murphy, K.C., Campellone, K.G. \& Poteete, A.R. PCR-mediated gene replacement in Escherichia coli. Gene 246, 321-330 (2000).

42. Zhang, Y., Buchholz, F., Muyrers, J.P. \& Stewart, A.F. A new logic for DNA engineering using recombination in Escherichia coli. Nat. Genet. 20, 123-128 (1998).

43. Zhang, Y., Muyrers, J.P., Testa, G. \& Stewart, A.F. DNA cloning by homologous recombination in Escherichia coli. Nat. Biotechnol. 18 1314-1317 (2000).

44. Yu, D. et al. An efficient recombination system for chromosome engineering in Escherichia coli. Proc. Natl. Acad. Sci. USA 97, 5978-5983 (2000).

45. Warming, S., Costantino, N., Court, D.L., Jenkins, N.A. \& Copeland, N.G. Simple and highly efficient BAC recombineering using galK selection. Nucleic Acids Res. 33, e36 (2005).

46. Cassuto, E. \& Radding, C.M. Mechanism for the action of $l$ exonuclease in genetic recombination. Nat. New Biol. 229, 13-16 (1971).

47. Little, J.W. An exonuclease induced by bacteriophage I. II. Nature of the enzymatic reaction. J. Biol. Chem. 242, 679-686 (1967). 
48. Carter, D.M. \& Radding, C.M. The role of exonuclease and b protein of phage $\mathrm{I}$ in genetic recombination. II. Substrate specificity and the mode of action of lambda exonuclease. J. Biol. Chem. 246, 2502-2512 (1971).

49. Cassuto, E., Lash, T., Sriprakash, K.S. \& Radding, C.M. Role of exonuclease and $\mathrm{b}$ protein of phage $\mathrm{I}$ in genetic recombination. V. Recombination of $\mathrm{l}$ DNA in vitro. Proc. Natl. Acad. Sci. USA 68, 1639-1643 (1971).

50. Sadowski, I., Ma, J., Triezenberg, S. \& Ptashne, M. GAL4-VP16 is an unusually potent transcriptional activator. Nature 335, 563-564 (1988).

51. Köster, R.W. \& Fraser, S.E. Tracing transgene expression in living zebrafish embryos. Dev. Biol. 233, 329-346 (2001).

52. Sternberg, N. \& Hamilton, D. Bacteriophage P1 site-specific recombination: I. Recombination between loxP sites. J. Mol. Biol. 150, 467-486 (1981).
53. Suster, M.L., Kikuta, H., Urasaki, A., Asakawa, K. \& Kawakami, K. Transgenesis in zebrafish with the tol2 transposon system. Methods Mol. Biol. 561, 41-63 (2009).

54. Baier, H. \& Scott, E.K. Genetic and optical targeting of neural circuits and behavior-zebrafish in the spotlight. Curr. Opin. Neurobiol. 19, 553-560.

55. Friedenreich, H. \& Schartl, M. Transient expression directed by homologous and heterologous promoter and enhancer sequences in fish cells. Nucleic Acids Res. 18, 3299-3305 (1990).

56. Datta, S., Costantino, N. \& Court, D.L. A set of recombineering plasmids for Gram-negative bacteria. Gene 379, 109-115 (2006).

57. Lister, J.A., Robertson, C.P., Lepage, T., Johnson, S.L. \& Raible, D.W. nacre encodes a zebrafish microphthalmia-related protein that regulates neuralcrest-derived pigment cell fate. Development 126, 3757-3767 (1999). 